Review

\title{
Beekeeping and honey bee colony health: A review and conceptualization of beekeeping management practices implemented in Europe
}

\author{
Giorgio Sperandio $^{\mathrm{a}, \mathrm{b}, *}$, Anna Simonetto ${ }^{\mathrm{a}, \mathrm{b}}$, Edoardo Carnesecchi ${ }^{\mathrm{c}, \mathrm{d}}$, Cecilia Costa ${ }^{\mathrm{e}}$, Fani Hatjina ${ }^{\mathrm{f}}$, \\ Simone Tosi ${ }^{\mathrm{g}}$, Gianni Gilioli ${ }^{\mathrm{a}}$ \\ a Department of Molecular and Translational Medicine, University of Brescia, Brescia, Italy \\ b Department of Life Sciences, University of Modena and Reggio Emilia, Reggio Emilia, Italy \\ ' Department of Environmental Health Sciences, Mario Negri Institute for Pharmacological Research IRCCS, Milan, Italy \\ d Institute for Risk Assessment Sciences (IRAS), Utrecht University, Utrecht, Netherlands \\ e CREA Research Centre for Agriculture and Environment, Bologna, Italy \\ f Division of Apiculture, Hellenic Agricultural Organisation 'DEMETER', Nea Moudania, Greece

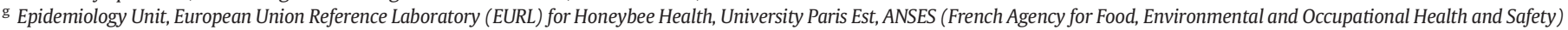 \\ Animal Health Laboratory, Maisons-Alfort, France
}

\section{H I G H L I G H T S}

- A review investigating the role of the beekeeper to honey bee colonies is presented.

- Independent drivers influence timing and effectiveness of beekeeping practices.

- A framework defining the effects of six beekeeping practices to bees is applied.

- The framework is adaptable to quantify any practice carried out by the beekeeper.

\section{A R T I C L E I N F O}

\section{Article history:}

Received 30 April 2019

Received in revised form 3 August 2019

Accepted 4 August 2019

Available online 06 August 2019

Editor: Damia Barcelo

\section{Keywords:}

Apiculture

Bee health

Beekeeping practice

Apis mellifera
GRAPHICAL A B S T R A T

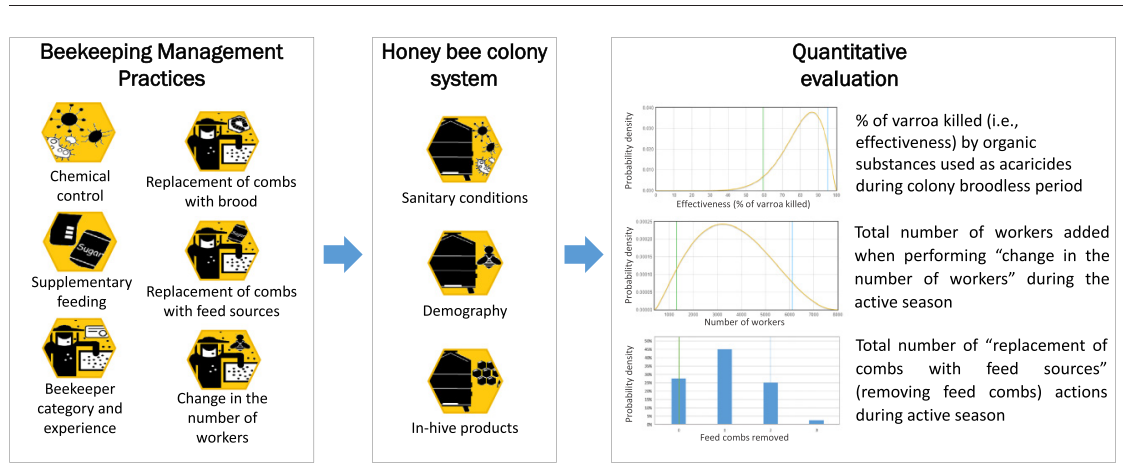

\begin{abstract}
A B S T R A C T
The beekeeper plays a key role in maintaining the health status of managed honey bee colonies and ensuring their productivity. However, a clear overview on the main actions carried out by beekeepers and their role for the successful management of honey bees is only partially addressed. In this study, we aim at providing: i) a generalized conceptual framework for the characterization of the Beekeeping Management Practices carried out by the European beekeepers and ii) the definition of their influence on the overall status of the honey bee colony. Six Beekeeping Management Practices were selected in this study: chemical control; replacement of combs with brood; replacement of combs with feed sources; supplementary feeding; change in the number of workers; beekeeper category and experience. Each Beekeeping Management Practice was characterized in relation to: i) the elements guiding their application, ii) the potential impacts on a honey bee colony and iii) the scenario-based variables that might influence their timing, frequency and/or efficiency. We performed an extensive literature review and an Expert Knowledge Elicitation procedure in order to estimate the uncertainty linked to some major parameters. In this paper, we successfully developed and applied a conceptual framework defining the actions
\end{abstract}

\footnotetext{
* Corresponding author at: Dep. of Molecular and Translational Medicine, University of Brescia, Viale Europa, 11, 25123 Brescia, Italy.

E-mail address: giorgio.sperandio@unibs.it (G. Sperandio).
} 
carried out by European beekeepers and quantifying their impacts to a honey bee colony. The conceptual framework might support the definition of realistic scenarios of Beekeeping Management Practices in Europe for the assessment and management of the risks linked to honey bee colonies considering the potential role of the beekeeper.

\section{Contents}

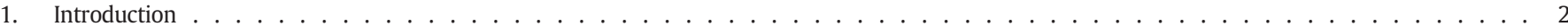

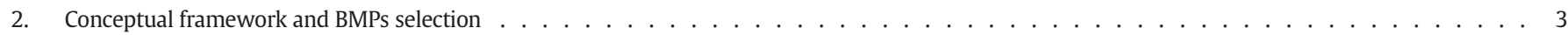

2.1. Review of scientific evidence . . . . . . . . . . . . . . . . . . . . . . . . . . . . . . . . . . 4

2.2. Expert knowledge elicitation. . . . . . . . . . . . . . . . . . . . . . . . . . . . . . . . . . 4

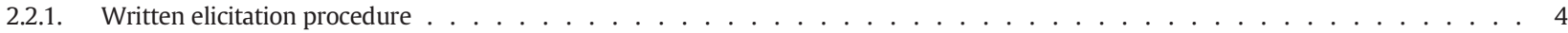

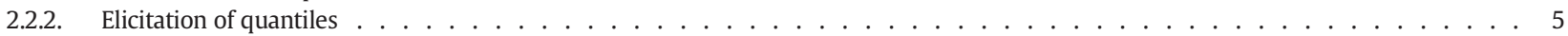

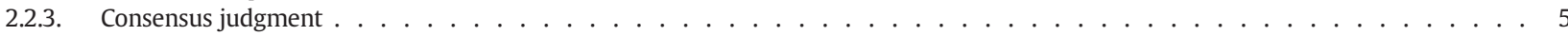

2.2.4. Uncertainty distribution curves fitting . . . . . . . . . . . . . . . . . . . . . . . . . . . . 5

3. Chemical control: guiding principles for application and effects . . . . . . . . . . . . . . . . . . . . . . . . . . 5

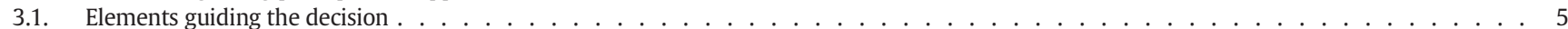

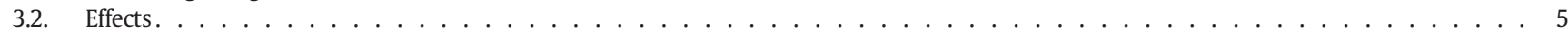

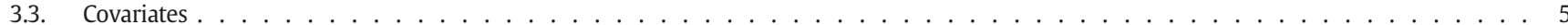

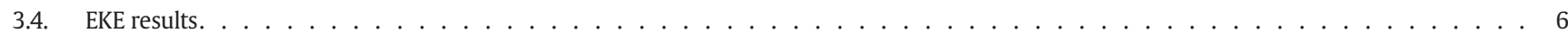

4. Replacement of combs with brood: guiding principles for application and effects . . . . . . . . . . . . . . . . . . . . . . . . . . . . 6

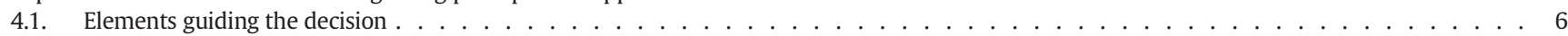

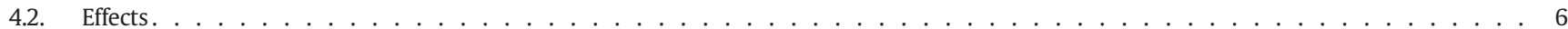

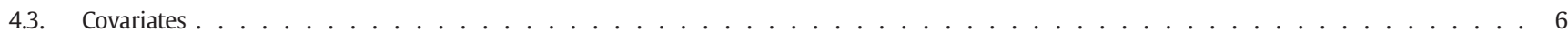

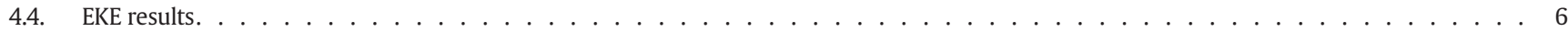

5. Replacement of combs with feed sources: guiding principles for application and effects . . . . . . . . . . . . . . . . . . . . . . . . . . . 7

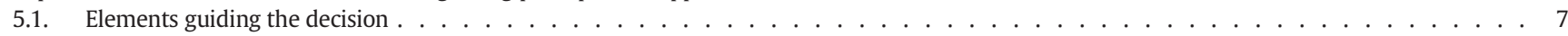

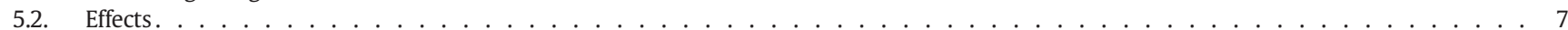

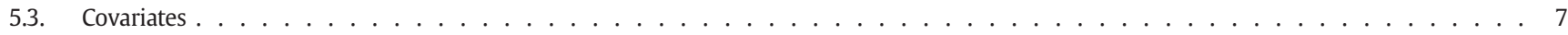

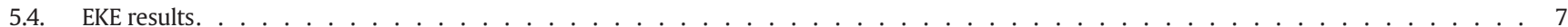

6. Supplementary feeding: guiding principles for application and effects . . . . . . . . . . . . . . . . . . . . . . . 7

6.1. Elements guiding the decision . . . . . . . . . . . . . . . . . . . . . . . . . . . . . 7

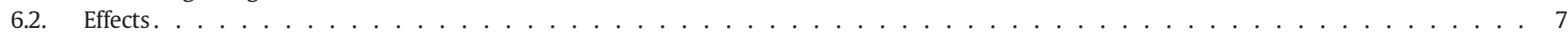

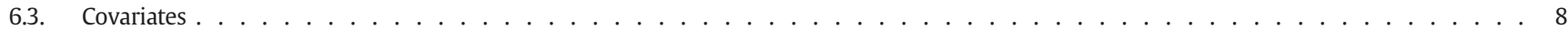

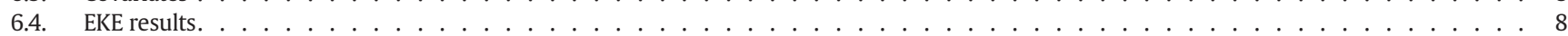

7. Change in the number of workers: guiding principles for application and effects. . . . . . . . . . . . . . . . . . . 8

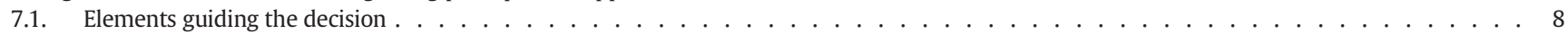

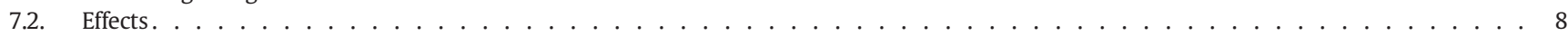

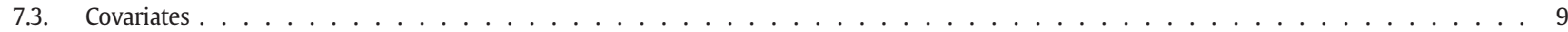

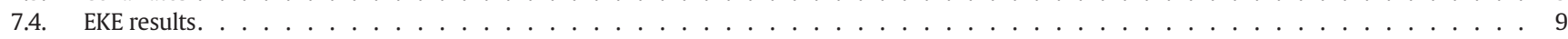

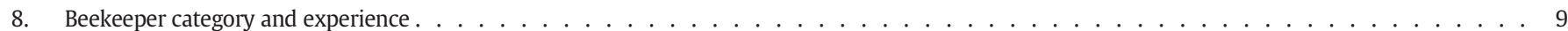

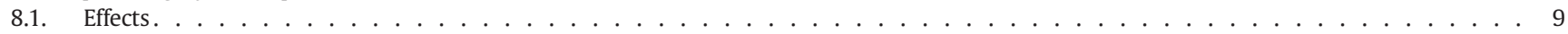

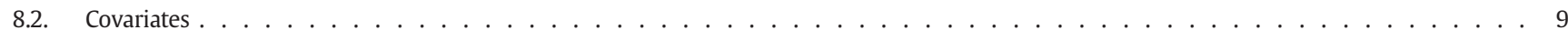

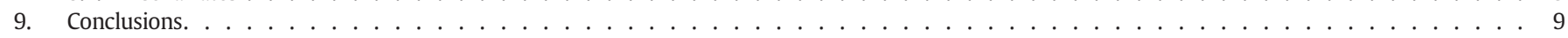

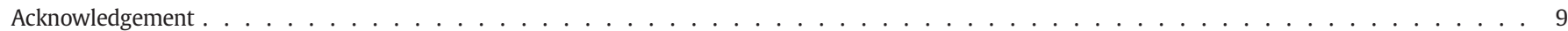

Appendix A. Supplementary data . . . . . . . . . . . . . . . . . . . . . . . . . . . . . . . . . . . . . . . . .

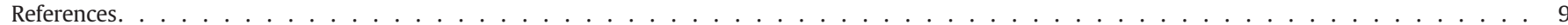

\section{Introduction}

Honey bees (Apis mellifera) have been managed for several millennia by humans (Crane, 2004). They have been used for the production of honey, beeswax, royal jelly, propolis, pollen, and venom. Beekeepers also produce queens, nucs, package bees, and use bees for the provision of pollination services (Mizrahi and Lensky, 1997; Schmidt, 1997; Formato and Smulders, 2011; Pufal et al., 2017). Honey bee pollination is considered essential for the production of fruits, seeds and vegetables (Bommarco et al., 2012; Rose et al., 2014) and for the maintenance of wild plant communities and biodiversity (De groot et al., 2002; Ashman et al., 2004; Aguilar et al., 2006). The annual monetary value of pollination services has been estimated at 22 billion $€$ (Deloitte, 2013). Beekeeping is an important sector of the European agricultural and food production system generating employment and increasing incomes in rural areas (Ritter and Akratanakul, 2006). According to European Commission (2016), around 600,000 European beekeepers (managing around 16 million honey bee colonies) produce around 250,000 tons of honey per year, generating more than 400 million $€$ per year in the EU. The consistent loss of honey bee colonies reported in Europe in the last decade (Neumann and Carreck, 2010; Cepero et al., 2014) was attributed to various factors, acting in isolation or in combination (Goulson et al., 2015; Renzi et al., 2016; Steinhauer et al., 2018). These factors include agrochemicals (Johnson et al., 2010; Henry et al., 2014; Dively et al., 2015; Brandt et al., 2016; Spurgeon et al., 2016), parasites and/or pathogens (Cox-Foster et al., 2007; Higes et al., 2009; Cornman et al., 2012; Zheng et al., 2015; Di Prisco et al., 2016), nutrition (Tosi et al., 2017), landscape management (Brosi et al., 2007; Naug, 2009; Decourtye et al., 2010), climatic conditions (Burkle et al., 2013; Odoux et al., 2014), genetic origin of bees 
(Büchler et al., 2014) and Beekeeping Management Practices (Chauzat et al., 2016; Jacques et al., 2016). Beekeeping Management Practices (BMPs) represent the actions implemented by a beekeeper (according to season, legislation, geographic area, cultural background etc.) to maintain healthy honey bee colonies and to achieve his/her agricultural and food production objectives (Ritter and Akratanakul, 2006; EFSA AHAW Panel, 2016). Several national and European monitoring projects, such as APENET (Porrini et al., 2016), the German Bee Monitoring Project (Genersch et al., 2010), EPILOBEE (Laurent et al., 2015; Chauzat et al., 2016) and COLOSS (Gray et al., 2019) highlighted the direct and/or indirect role of the beekeeper in preserving the health and ensuring the productivity of honey bee colonies. For instance, the prevalence of pathogens, the status of the queen, and the availability of food are potentially linked to the role of the beekeeper and her/his ability to successfully manage the colony. Moreover, Brodschneider et al. (2016) and Jacques et al. (2017) found that the size of the apiary, the age and the experience of the beekeeper are factors directly linked to the survival of the honey bee colony. In Europe, BMPs vary greatly across member states. These differences are mainly driven by socio-economic conditions, colony demography, landscape characteristics and climatic conditions (Deloitte, 2013; Chauzat et al., 2014). For instance, the type of supplementary feed provided by beekeepers as well as the timing, frequency and efficiency of anti-varroa treatments are highly related to climatic conditions (DeGrandi-Hoffman and Curry, 2004; Akyol et al., 2006). Knowing the influence of BMPs to honey bee colonies might support the development of more realistic scenarios for the assessment and management of bee health. On this regard, in 2015 the European Food Safety Authority (EFSA) launched a project named MUST-B: EU efforts towards the development of a holistic approach for the risk assessment on Multiple Stressors on Bees (EFSA, 2016; EFSA AHAW Panel, 2016; Rortais et al., 2017). The project aims at the exploration of how multiple stressors and factors affect honey bee colonies. Within the MUST-B framework, detailed information on the main BMPs carried out by European beekeepers and a qualitative description of their influence to the health and to the overall status of a managed honey bee colony were provided.

The aim of our paper is to: (i) develop a generalized conceptual framework for further defining the influence of BMPs to a honey bee colony and (ii) quantitative estimate the scenario-specific variability in timing, frequency and efficiency of BMPs carried out by European beekeepers throughout Expert Knowledge Elicitation (EKE). The proposed conceptual framework was applied to six
BMPs namely: chemical control; replacement of combs with brood; replacement of combs with feed sources; supplementary feeding; change in the number of workers; beekeeper category and experience.

\section{Conceptual framework and BMPs selection}

In our study, the honey bee colony system consisted by three components: demography, sanitary conditions and in-hive products (Fig. 1). The selection of the most relevant BMPs in Europe was based on the work done by EFSA and the EFSA Panel on Animal Health and Welfare (AHAW) (EFSA, 2016; EFSA AHAW Panel, 2016) and followed a two-step procedure. As a first step, 14 BMPs widely applied in Europe were identified and classified according to three evaluation criteria:

1. Relevance for the health status of a managed honey bee colony: whether there is an evidence suggesting an association between the BMP and bee health (High-Low);

2. Technical feasibility in the context of field surveys: whether the measurement of the BMP could be routinely done by a beekeeper in the context of a field survey (High-Low);

3. Priority for inclusion in field surveys across EU: whether the ratio between the benefit of the data collected on a certain BMP and the efforts in terms of resources is considered high. In addition, the factor is highly relevant to most member states and in most conditions (High-Medium-Low).

The BMPs that scored High on the three evaluation criteria $(\mathrm{HHH}$, meaning High relevance, $\overline{\text { High }}$ technical feasibility and High priority) were considered for further selection. The second step of the selection procedure aimed at evaluating the influence of the BMPs (Yes-No) on the above-mentioned components of the honey bee colony system (demography, sanitary conditions and in-hive products). A total of six BMPs having a direct and/or indirect influence on the three components of the honey bee colony system were selected (Table 1). Five BMPs refer to events triggered by one or more internal or external factors: chemical control, replacement of combs with brood, replacement of combs with feed sources, supplementary feeding and change in the number of workers. The remaining BMP, namely beekeeper category and experience, is not an event and further defines the characteristics of the

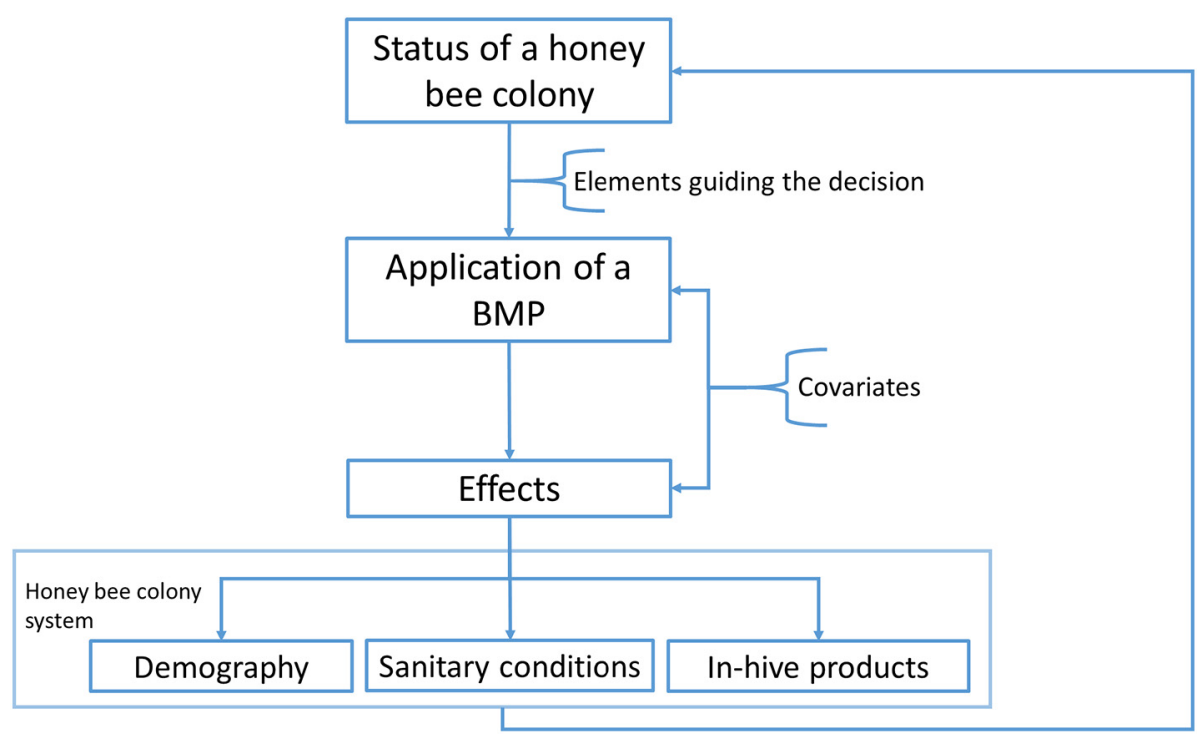

Fig. 1. Conceptual framework showing the main relationships existing between BMPs and the honey bee colony system. 
Table 1

Overview of the selection criteria applied to BMPs at EU level, modified from EFSA (2016) and EFSA AHAW Panel (2016).

\begin{tabular}{|c|c|c|c|c|c|c|c|}
\hline \multirow[t]{2}{*}{ Beekeeping Management Practices } & \multicolumn{3}{|c|}{ 1st step selection } & \multicolumn{3}{|c|}{ 2nd step selection } & \multirow[t]{2}{*}{ Final selection } \\
\hline & Relevance & Technical feasibility & Priority & Demography & Sanitary conditions & In-hive products & \\
\hline Chemical control & $\mathrm{H}$ & $\mathrm{H}$ & $\mathrm{H}$ & Yes & Yes & Yes & Yes \\
\hline Replacement of combs with brood & $\mathrm{H}$ & $\mathrm{H}$ & $\mathrm{H}$ & Yes & Yes & Yes & Yes \\
\hline Replacement of combs with feed sources & $\mathrm{H}$ & $\mathrm{H}$ & $\mathrm{H}$ & Yes & Yes & Yes & Yes \\
\hline Supplementary feeding & $\mathrm{H}$ & $\mathrm{H}$ & $\mathrm{H}$ & Yes & Yes & Yes & Yes \\
\hline Beekeeper category and experience & $\mathrm{H}$ & $\mathrm{H}$ & $\mathrm{H}$ & Yes & Yes & Yes & Yes \\
\hline Change in the number of workers & $\mathrm{H}$ & $\mathrm{H}$ & $\mathrm{H}$ & Yes & Yes & Yes & Yes \\
\hline Migration activity & $\mathrm{H}$ & $\mathrm{H}$ & $\mathrm{H}$ & No & No & Yes & No \\
\hline Introduction of a queen bee & $\mathrm{H}$ & $\mathrm{H}$ & $\mathrm{H}$ & Yes & No & Yes & No \\
\hline Proximity of colonies belonging to other apiaries & $\mathrm{H}$ & $\mathrm{H}$ & $\mathrm{H}$ & Yes & No & No & No \\
\hline Location of the apiary & $\mathrm{H}$ & $\mathrm{H}$ & $\mathrm{H}$ & No & No & No & No \\
\hline Production type of the colony & $\mathrm{H}$ & $\mathrm{H}$ & $\mathrm{H}$ & No & No & No & No \\
\hline Physical/mechanical control methods & $\mathrm{H}$ & $\mathrm{H}$ & M & - & - & - & - \\
\hline Swarm control & $\mathrm{H}$ & $\mathrm{H}$ & M & - & - & - & - \\
\hline Size of apiary & $\mathrm{H}$ & $\mathrm{H}$ & M & - & - & - & - \\
\hline Introduction of comb foundation & $\mathrm{H}$ & $\mathrm{H}$ & $\mathrm{L}$ & - & - & - & - \\
\hline Biological control methods & $\mathrm{L}$ & - & - & - & - & - & - \\
\hline
\end{tabular}

beekeeper. The selected BMPs were further characterized by three descriptors:

- Elements guiding the decision (not applicable for beekeeper category and experience): specific internal (colony level) or external (landscape level) factors triggering the application of a BMP. The information was reported in a qualitative or, when applicable, quantitative form;

- Effects: referring to the direct and/or indirect influence of a BMP to one or more target components of the honey bee colony system. The information was reported under qualitative or, when applicable, quantitative form;

- Covariates: independent internal or external variables influencing the timing, the frequency of application or the efficiency of a BMP. The information was reported in a qualitative or, when applicable, quantitative form.

\subsection{Review of scientific evidence}

Relevant information and knowledge on the six selected BMPs were collected from EFSA (2016) and EFSA AHAW Panel (2016). Furthermore, we performed ad-hoc literature searches aimed at collecting and reviewing the available evidence to: i) further describe each BMP; ii) define the scenarios under which each BMP is applied; iii) identify the covariates influencing the timing, frequency and effectiveness of the BMPs. Literature search was carried out using Scopus database according to the following search strategies:

- Chemical control: (honeybee OR "honey bee" OR honey-bee OR “Apis mellifera" OR "A. mellifera" OR beekeep*) AND (anti-varroa OR "anti varroa" OR "again* varroa" OR "varroa treat*");

- Replacement of combs with brood: (honeybee OR "honey bee" OR honey-bee OR "Apis mellifera" OR "A. mellifera" OR beekeep*) AND ("comb* with brood" OR "brood comb*");

- Replacement of combs with feed sources: (honeybee OR "honey bee" OR honey-bee OR "Apis mellifera" OR "A. mellifera" OR beekeep*) AND ("food comb*" OR "comb* with food" OR "feed comb*" OR "comb* with feed" OR feed OR "honey comb*" OR "pollen comb*" OR "beebread comb");

- Supplementary feeding: (honeybee OR "honey bee" OR honey-bee OR "Apis mellifera" OR "A. mellifera" OR beekeep*) AND ("supplement* feed*" OR "supplement* food*" OR syrup* OR cand*);

- Change in the number of workers: (honeybee OR "honey bee" OR honey-bee OR "Apis mellifera" OR "A. mellifera" OR beekeep*) AND ("worker* comb*" OR "comb* with worker*" OR "add* worker*" OR

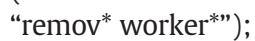

- Beekeeper category and experience: (beekeeper* OR "bee keeper*" OR bee-keeper* OR honeybee OR "honey bee" OR honey-bee OR "Apis mellifera" OR “A. mellifera") AND (categor* OR experience*).

\subsection{Expert knowledge elicitation}

Expert Knowledge Elicitation (EKE) is a structured methodology for consulting experts' knowledge on topics where there is limited (or not available) scientific evidence or, alternatively, to make explicit and synthesise published and unpublished knowledge of experts (Knol et al., 2010). In our study, the potential influence of BMPs on the honey bee colony, the application and the efficiency of a BMP under different scenarios potentially occurring in Europe were quantified throughout an EKE procedure according to a simplified Sheffield methodology (EFSA, 2014). The results were reported under the form of uncertainty distributions (EFSA, 2018). Three experts involved in honey bee research and with relevant expertise in beekeeping were involved in the EKE procedure. The EKE foresaw four phases: i) written elicitation procedure, ii) elicitation of quantiles of the uncertainty distributions, iii) group judgment among experts on the estimated quantiles and iv) uncertainty distribution curve fitting. Preparatory material (including the scientific literature collected), training and practical tutorials were provided to the involved experts prior the EKE procedure.

\subsubsection{Written elicitation procedure}

The written elicitation procedure was performed by means of an elicitation protocol (Appendix A). The elicitation protocol reported 31 questions covering the major data and information gaps identified for five out of the six BMPs under investigation (Table 2). The BMP beekeeper category and experience was not included into the protocol since the information available in literature was sufficient to characterize it. The scenarios under which contextualizing each question was

Table 2

Summary table showing the number of questions for each BMP asked to the experts during the EKE procedure.

\begin{tabular}{lc}
\hline BMP & Number of questions \\
\hline Chemical control & 4 \\
Replacement of combs with brood & 7 \\
Replacement of combs with feed sources & 4 \\
Supplementary feeding & 14 \\
Change in the number of workers & 2 \\
Total & 31 \\
\hline
\end{tabular}


clearly indicated, both in temporal (e.g. during the period of activity of the colony, during broodless period etc.) and spatial terms (e.g. the whole population of European beekeepers, beekeepers of north, central or south Europe). The elicitation protocol included a general and a BMPspecific glossary explaining the terminology used.

\subsubsection{Elicitation of quantiles}

The three experts involved in the EKE procedure individually and independently answered to the questions presented in the elicitation protocol. The responses were provided under the form of probability distributions by identifying the $5^{\text {th }}(\mathrm{Q} 1)$, the $50^{\text {th }}(\mathrm{Q} 2)$ and the $95^{\text {th }}$ (Q3) quantile. The suggested criterion for answering the questions was first to identify the lowest and the highest quantiles (Q1 and Q3 respectively), then to identify the median (Q2). Experts were solicited to justify their choices by citing relevant publications or through a statement. Each question was answered under the assumption that Good Beekeeping Practices were applied by beekeepers.

\subsubsection{Consensus judgment}

According to the independent answers provided by the experts, the elicitor proposed a set of quantiles of the uncertainty distribution for each question and shared it with the whole group of experts. Experts were asked to check whether the proposed outcome reflected their thoughts and, if not, to revise the quantiles accordingly. Afterwards, the elicited quantiles related to each question were discussed between the three experts with the support and coordination of the elicitor until reaching a consensus among experts (behavioural aggregation) (EFSA, 2014). The agreed quantiles were assumed as the quantification of the best available knowledge of the experts involved.

\subsubsection{Uncertainty distribution curves fitting}

The MATCH Uncertainty Elicitation Tool (Morris et al., 2014) was used to fit uncertainty distribution curves based on the agreed quantiles for the 31 elicited questions. The results of the EKE procedure are reported in Tables S1-S31.

\section{Chemical control: guiding principles for application and effects}

This BMP refers to chemical treatments administered by the beekeeper to the colony with the aim of controlling a biological agent. The acari Varroa destructor is the main biological agent for which authorised products exist in Europe (Commission Regulation EC No 470/2009, European Commission, 2009). Generally, chemical control practices include synthetic (e.g. fluvalinate), and organic (e.g. oxalic acid, thymol) miticides (EFSA AHAW, 2016). Thus, we focused our investigation on both synthetic and organic (coupled with apicultural techniques) treatments applied for controlling varroa population.

\subsection{Elements guiding the decision}

When varroa infestation levels on adult bees are above $3 \%$ (i.e. three varroa mites per 100 honey bees), a varroa control treatment is suggested (Charriére and Imdorf, 2002). However, beekeepers use varroa control methods even as a precaution (e.g. when varroa infestation is below the 3\% threshold). Anti-varroa treatments are usually applied at the beginning of the apicultural season, at the end of honey harvesting and before winter period (with preference to treat when brood is not present in the colony) (Charriére and Imdorf, 2002). Usually chemical treatments are not applied when supers are placed on the top of the hive in order to avoid honey contamination. In this case, mechanic apicultural techniques (e.g. brood removal, block of egg laying, formation of new nuclei) may be applied for controlling varroa populations.

\subsection{Effects}

- Demography: honey bees can be exposed to chemical residues via contact and oral pathways, that could lead to acute and chronic, lethal and sub-lethal adverse side effects on all bee stages and castes (Johnson, 2015). Exposure to synthetic acaricides might lead to increased larval (Gregorc and Bowen, 2000; Zhu et al., 2014) and adult mortality (Wu et al., 2011; Dahlgren et al., 2012; Garrido et al., 2013), reduced queen survival, weight and fecundity (Whittington et al., 2000; Haarmann et al., 2002; Pettis et al., 2004; Dahlgren et al., 2012; Rangel and Tarpy, 2015) and atypical behaviours (Maggi et al., 2008). Organic treatments (e.g. oxalic acid) can cause sublethal effects to honey bees (Schneider et al., 2012). Details on the dose-response curves, $\mathrm{LD}_{50}$ and $\mathrm{LC}_{50}$ of several acaricides for bees are available in Atkins et al. (1981), Aliano et al. (2006), Maggi et al. (2008), Dahlgren et al. (2012), Garrido et al. (2013). Exposure to these chemicals can alter the susceptibility of bees to biological agents and/or to other chemicals (Boncristiani et al., 2012; Johnson et al., 2013; Schmehl et al., 2014). The toxicity of chemicals can also reduce bee health and survival synergistically, amplifying the adverse effect on bees when occurring in combinations with a nutritional stress (Tosi et al., 2017), a disease (Collison et al., 2016), or another chemical (Johnson et al., Deloitte, 2013), although literature data is still limited on this topic;

- Sanitary conditions: the use of (synthetic or organic) chemical treatments according to Good Beekeeping Practices reduces the abundance of varroa population in the hive (Rademacher and Harz, 2006) preventing the transmission of viruses or other diseases within the honey bee colony (Le Conte et al., 2010; Nazzi et al., 2012; Emsen et al., 2015);

- In-hive products: veterinary medicinal products containing synthetic compounds used for varroa control are usually applied inside the hive and sometimes are left in the colony for several weeks (e.g. commercial formulations of tau-fluvalinate and amitraz). Therefore they are often found as residues in various bee matrices such as wax, beebread and honey (Floris et al., 2001; Bogdanov, 2006; Martel et al., 2007; Lodesani et al., 2008; Johnson et al., 2010; Mullin et al., 2010; Boi et al., 2016; Codling et al., 2016; Porrini et al., 2016). In contrast, organic treatments based on oxalic acid do not seem to accumulate in honey matrix (Bogdanov et al., 2002). However, as most of the synthetic acaricides are lipophilic substances (Bogdanov, 2006), a higher concentration is expected in beeswax and, depending on the concentration of the chemical in this matrix, migration processes among different bee matrices are expected (e.g. from wax to beebread or from wax to honey) (Lodesani et al., 2008; Johnson et al., 2013; Shimshoni et al., 2019).

\subsection{Covariates}

The type of treatment (synthetic or organic), the type of chemical and its allowed concentration may vary according to legislations applied in different European countries (Mutinelli and Rademacher, 2003; Mutinelli, 2016). Registration and authorization facilitates the use of a certain chemical product. For instance, the recent authorization of products containing thymol (EMA, 2013) facilitated their use among European member states. A strategy combining treatment with formic acid in summer and oxalic acid in winter was by far the most commonly applied in the continental and subarctic areas of Europe (van der Zee et al., 2014). The majority of beekeepers from continental and subarctic areas successfully treat varroa only in winter, confirming that winter treatment against varroa might be sufficient, while multiple treatments or the application of a combination of treatments during the whole year are demanded in several areas of the Mediterranean countries (Lodesani et al., 2014). Chemicals may also be selected taking into account varroa resistance phenomena. Using the same product for several 
consecutive years might increase varroa tolerance and decreases chemical treatment efficiency (Lodesani and Costa, 2005; Sammataro et al., 2005). Varroa treatments are more effective in climatic regions characterized by a winter broodless period because phoretic mites are more susceptible to control products. For instance, oxalic acid have an efficacy greater than $90 \%$ when applied during broodless period while the efficacy falls to $60 \%$ (or lower) for colonies containing brood (Rademacher and Harz, 2006; Rosenkranz et al., 2010; van der Zee et al., 2014). Shorter summers result in fewer mite reproduction cycles and thus a lower level of infestation (Giacobino et al., 2016). In Europe there are areas in which brood is reared during the whole year, while in others (e.g. the subarctic and the continental areas) brood interruption occurs during the winter months (van der Zee et al., 2014). Thus, higher concentration of chemicals are needed in southern regions to obtain the same results as in central and northern regions because of the lack (or the limited duration) of the broodless period.

\subsection{EKE results}

Given the strong relation existing between the seasonality and the presence/absence of brood on the efficiency of anti-varroa treatments, four EKE questions were related on the efficiency (i.e. percentage of varroa killed) of synthetic and organic treatments either during brood or broodless period (Tables S1-S4). The highest efficiency was reached by synthetic ( $\mathrm{Q} 1=58.25 ; \mathrm{Q} 2=87.18 ; \mathrm{Q} 3=98.7)$ and organic $(\mathrm{Q} 1$ $=59.39 ; \mathrm{Q} 2=82.5 ; \mathrm{Q} 3=95.25$ ) treatments during broodless period. The estimated efficiency was lower for synthetic (Q1 = 24.41; Q2 = 45.09; $\mathrm{Q} 3=67.02)$ and $\operatorname{organic}(\mathrm{Q} 1=20.07$; $\mathrm{Q}=43.98$; $\mathrm{Q} 3=$ 70.08) anti-varroa treatments applied during brood period.

\section{Replacement of combs with brood: guiding principles for applica- tion and effects}

This BMP refers to the action of transferring one or more brood combs from a honey bee colony (donor) to another one (receiver).

\subsection{Elements guiding the decision}

This BMP is applied for different purposes highly dependent on the beekeeper's specific goals. Brood combs are removed from a donor colony which is typically 'strong' (i.e. with high number of adult bees and brood combs), and introduced into a receiver colony, typically 'weaker', to increase the number of brood cells, which will emerge as adult bees within the following 3 weeks. The number of worker bees performing nursing tasks in the receiver colony should be sufficient to cope with the increased amount of open brood, which will need feeding. Therefore, beekeepers usually seek to transfer capped brood (which does not need feeding, but only heating). Replacement of brood combs may be used to homogenize the size of the colonies within an apiary (thus preventing robbing behaviour between colonies and supporting a more uniform honey production per colony). Reducing the amount of brood in a colony is also used as a technique to prevent swarming behaviour and to reduce varroa mite infestation levels (alone or in combination with chemical treatments or mechanical techniques), because the varroa mite reproduces inside the capped brood (Calis et al., 1998; Gregorc et al., 2017). Removed brood combs can be used for producing new colonies, or for the production of nukes. Together with brood, moving frames may involve also the movement of feed sources and adult bees.

\subsection{Effects}

- Demography: the main direct effect of applying this BMP is changing the demography of both donor and receiver honey bee colony. Secondary effects are related to colony physiological and behavioural modifications due to the changed demography. The new adult/ brood rate can alter the tasks division (e.g. the number of bees performing nursing tasks must be adequate in order to feed and heat the brood), the time and the energy allocation of bees (Filmer, 1932; Allen and Jeffree, 1956; Le Conte et al., 2001; Pankiw, 2004; Pankiw et al., 2004). Since egg-laying rate depends on demography and food availability, the application of this BMP influences the oviposition rate of the queen (Harbo, 1986). Introduced combs might be contaminated with chemical residues (Floris et al., 2001; Bogdanov, 2006; Martel et al., 2007; Lodesani et al., 2008; Johnson et al., 2010; Mullin et al., 2010; Codling et al., 2016; Porrini et al., 2016) potentially leading to an increased exposure of the receiver colony to chemicals. The donor colony will experience a decreased amount of brood. Consequently, the number of bees performing nursing will decrease in favour to other tasks (e.g. cleaning the hive, foraging etc.);

- Sanitary conditions: introduced combs may contain infectious agents and pests (e.g. nosema, varroa and related viruses) thus potentially increasing the risks of contracting pathologies for the receiver colony (Bailey and Ball, 1991; Fries, 1993; Lindström et al., 2008; Porrini et al., 2016). Removing brood frames from healthy colonies, especially if combined with anti-varroa treatments, significantly reduces the abundance of varroa mites (Nanetti et al., 2016; Gregorc et al., 2017);

- In-hive products: the application of this BMP influences the amount of in-hive products available in both the donor (reduction in the amount of in-hive products) and the receiver (increase in the amount of inhive products) colonies. An initial increase on energetic expenditure is required from the receiver colony in order to rear the newly received brood. After the emergence of the newly hatched bees, the increased amount of adults will lead to an increased collection of nectar and pollen.

\subsection{Covariates}

Timing and frequency on the application of this BMP highly depends on the overall status of the honey bee colony and on the season. The success in the application of this BMP depends on the ratio between sealed and unsealed brood present in the transferred comb. The presence of unsealed brood will increase the overall energetic needs of the receiver colony to rear the new larvae. Therefore, if nurse bees belonging to the receiver colony are not sufficient to rear the newly introduced brood the efficiency of this BMP might be reduced (Eischen et al., 1984).

\subsection{EKE results}

In the EKE we assumed that a standard brood comb is composed only by brood and feed. Five questions were related to quantifying the composition of a brood comb in terms of brood (percentage of comb surface covered by eggs, larvae and pupae) and feed (percentage of comb surface covered by honey and beebread). Answers are reported in Tables S5-S9. Experts reported that, when possible, beekeepers prefer to move combs containing a higher number of capped brood (i.e. pupae) respect to open brood (eggs and larvae) in order to avoid the extra food demand needed by the receiver colony to feed larvae. This was reflected by the estimated composition of a standard brood comb. The estimated values representing the percentage of surface coverage of a standard brood comb were 3.19 (Q1), 10.04 (Q2), 22.02 (Q3) for eggs, 4.57 (Q1), 15.15 (Q2), 35.93 (Q3) for larvae and 39.24 (Q1), $65.28(\mathrm{Q} 2), 86.10(\mathrm{Q} 3)$ for pupae. Experts also quantified the percentage of comb surface covered by beebread $(\mathrm{Q} 1=3.58$; Q2 $=9.95$; $\mathrm{Q} 3$ $=20.54)$ and honey $(\mathrm{Q} 1=9.93 ; \mathrm{Q} 2=15.58 ; \mathrm{Q} 3=22.64)$. Considering that this BMP is not applied during winter (i.e. no actions carried out on a honey bee colony during this period), two additional questions were aimed at estimating the number of combs added and removed per colony during the active season (Tables S10 and S11; Q1 = 0; Q2 = 1; Q3 = 2). 


\section{Replacement of combs with feed sources: guiding principles for application and effects}

This BMP refers to adding or removing feed combs (filled with honey and/or beebread stores) from a donor to a receiver colony. The feed combs used for harvesting honey were not considered in this BMP.

\subsection{Elements guiding the decision}

Feed combs are typically moved from a colony with food surplus to colonies characterized by low food stores, at any time of the year in order to equalise colony strength and food availability (Gąbka, 2014). During the last colony check before winter, feed combs are usually replaced among colonies to ensure that each winter cluster of bees has sufficient food stores to last through the winter. This BMP may also be applied in early spring, before the beginning of the strong nectar flows, to support colonies with food deficit. Feed combs removed from colonies with food abundance can be used also for the production of new colonies.

\subsection{Effects}

- Demography: if adult bees are moved together with the comb, the quantity of adult bees increases in the receiver colony and decreases in the donor colony. Since egg-laying rate depends on demography and food availability, the application of this BMP influences queen oviposition rate (McLellan, 1978; Eischen et al., 1983; Mattila and Otis, 2006). This BMP can also influence comb building behaviour as the timing of comb building is influenced by two factors that must occur simultaneously: nectar availability/influx and stored food quantity/ comb fullness (Kelley, 1991; Seeley, 1995). The introduction of food combs carries risks related to the possible contamination by pesticides either used for beekeeping and/or agricultural treatments (Floris et al., 2001; Bogdanov, 2006; Martel et al., 2007; Lodesani et al., 2008; Johnson et al., 2010; Mullin et al., 2010; Codling et al., 2016; Porrini et al., 2016) possibly leading to an increased honey bee mortality;

- Sanitary conditions: the introduction of food combs carries risks related to the possible presence of biological agents such as Nosema spp., American and European foulbrood (Fries, 1993; Lindström et al., 2008; Porrini et al., 2016);

- In-hive products: the quantity of food introduced alters the nutritional status of the colony (i.e. in-hive products), increasing (receiver) or decreasing (donor) the quantity of available feed (Dadant, 1975; Seeley and Morse, 1976).

\subsection{Covariates}

Frequency of feed comb addition/removal highly depends on the presence and abundance of feed sources available in the colony as well as the availability of nectar and pollen in the landscape. Highly productive colonies might experience one or more feed comb removal in order to compensate low abundance of honey or beebread in other colonies, or for the production of nukes (Gąbka, 2014).

\subsection{EKE results}

With regards to the EKE procedure we assumed that a standard feed comb is composed only by honey and beebread, without considering bees moved together with the feed comb. This assumption is justified by the fact that beekeepers normally remove individual bees (by shaking the frame) before transferring the feed comb. Two questions were related to estimating the percentage of a standard feed comb surface covered by honey and beebread and other two questions to estimate the number of feed combs added to or removed from a colony during the active season, including the pre-wintering period (Tables S12-
S15). Feed comb surface was estimated as mainly covered by honey $(\mathrm{Q} 1=39.83 ; \mathrm{Q} 2=70.05$; $\mathrm{Q} 3=91.26)$. The median coverage of beebread was $15.28 \%(\mathrm{Q} 1=4.94 ; \mathrm{Q} 3=34.93)$. The number of feed combs added to or removed from a colony during the active season, including the pre-wintering period was 0 (Q1), 1 (Q2) and 2 (Q3).

\section{Supplementary feeding: guiding principles for application and effects}

Supplementary feeding refers to the practice of providing feed (i.e. sugar, proteins, amino acids, lipids, micronutrients and probiotics) in order to satisfy the colony nutritive requirements when natural food sources are inadequate for the maintenance of a healthy and productive colony.

\subsection{Elements guiding the decision}

Supplementary feeding is typically more common and intensively used in terms of quantity and frequency among professional beekeepers. Supplementary feed is usually provided to the colony through artificial supplements, mostly made of sugars, and can be liquid (i.e. syrups) or solid (i.e. candies). In almost all European countries, carbohydrate supplements are used: i) for colony stimulation during spring (using candy or syrup depending on the temperature); ii) for supporting colonies during dearth periods (usually with sugar syrup); iii) for preparing colonies to the winter period (using candy or thick syrup). In spring, supplementary feeding is often provided to boost colony development before important honey flows (such as Robinia pseudoacacia), even when natural resources are available. In summer, artificial feeding is provided only in case of scarce floral resources. In autumn and winter, supplementary feed is provided to ensure the survival of the colony during the non-active period. In some regions, after the last summer harvest, colonies are fed with up to $20 \mathrm{Kg}$ of sugar syrup as supply for winter periods (Brodschneider and Crailsheim, 2010). In southern countries where honey production continues until midNovember, candy is mainly used as supply for overwintering colonies, sometimes in combination with a more concentrated syrup. An important source of amino acids and proteins mainly used by beekeepers for boosting colony growth is represented by protein supplements. Pollen supplements are used in many countries (e.g. Denmark, Finland, Greece, Lithuania, Poland, Portugal, UK, Turkey) in cases of pollen shortage during spring and autumn (Mattila and Otis, 2006), while in other countries (e.g. Belgium) it is thought to be a more common practice (used by about $30-40 \%$ of the beekeepers). An example of the great need for protein supplements could be the case of South European countries where drought and limited supply of pollen at the end of the active season (e.g. autumn) may decrease colony size and production (Rashad and Parker, 1958).

\subsection{Effects}

- Demography: the correct application of this BMP increases the fecundity of the queen in spring/summer, (Somerville and Nicol, 2006; Dodologlu and Emsen, 2007; van der Steen, 2007; DeGrandiHoffman et al., 2008) and increases the longevity of immature and adult bees (Brodschneider and Crailsheim, 2010). If applied during period of food dearth, supplementary feed may prevent from events of brood cannibalisation (Schmickl and Crailsheim, 2001; DeGrandiHoffman et al., 2008). Because this BMP influences nutrients quality and quantity available to the colony, it could consequently influence bee susceptibility to stressors such as pesticides (Tosi et al., 2017), Nosema spp. (Lodesani et al., 2012; Di Pasquale et al., 2013) and viruses (DeGrandi-Hoffman et al., 2010). Carbohydrate supplements can protect bees from pesticide intoxication, since poor food quality and quantity (i.e. dearth) amplify pesticide side-effects synergistically (Tosi et al., 2017). A pollen or pollen-based supplementary feeding 
seems to have positive effects on the hypopharyngeal gland development and decrease the levels of Deformed Wing Virus. This indicates that colony losses might be reduced by alleviating protein stress through supplemental feeding (DeGrandi-Hoffman et al., 2010). However, there is a growing evidence that the use of protein supplements do not increase the health and strength of honey bees (DeGrandiHoffman et al., 2016; Mortensen et al., 2019) unless they are absolutely needed (e.g. when pollen available in the landscape is not enough to sustain colony survival). Therefore the best protein source for bees is considered pollen (DeGrandi-Hoffman et al., 2008; Saffari et al., 2010). Since pollen is frequently contaminated by multiple pesticides (Tosi et al., 2018), particular attention should be given to assessing the safety of the pollen used. Both syrup and candy supplements may contain sugars or pesticide residues that are toxic to bees (Codling et al., 2016; Porrini et al., 2016; Traynor et al., 2016) thus potentially increasing honey bee mortality;

- Sanitary conditions: the provision of supplementary feed may carry the risk of transferring viruses or spores of bacteria/fungi from the donor to the receiver colony. On the other hand, the correct application of this BMP might reduce bee susceptibility to biological agents (Nosema spp., viruses etc.) by increasing quality and quantity of available food (DeGrandi-Hoffman et al., 2010; Lodesani et al., 2012; Di Pasquale et al., 2013);

- In-hive products: the supplementation of sugars and proteins increases the quantity of food that is stored in the hive.

\subsection{Covariates}

There is a great variability in the amount and the type of feed supplements given to the colonies by beekeepers (even among the members of the same local community). Periods, quantity and frequency of supplementary feeding are influenced by climatic conditions, landscape structure (e.g. floral diversity) and colony production type (pollination services, royal jelly production, queen production etc.). In areas characterized by mild winters (and consequently short or absent broodless periods), honey bees might need a higher amount of supplementary feeding for rearing brood during the colder season. Colonies reared in cold areas usually need high protein supplementation (Mattila and Otis, 2006). Honey bees reared in areas characterized by cold and rainy springs might need supplementary feed until pollen and nectar could be collected from the field (Mattila and Otis, 2006).

\subsection{EKE results}

In the EKE protocol, experts were asked to quantify the percentage of carbohydrate and protein content of syrup, candy and protein supplement food and the total mass of these products used by beekeepers according to the three European climatic regions (north, centre, south) and considering seasonality (active and non-active period), when relevant (Tables S16-S29). It was assumed that syrup products are composed by water and carbohydrates only and they are mainly used during the active season (i.e. for colony stimulation at the beginning of the beekeeping season and during periods of food dearth) and before the wintering season (for providing feed before the beginning of the non-active season). The estimated percent concentration of carbohydrates in syrup provided during the active season was 41.77 (Q1), $50.16(\mathrm{Q} 2)$ and $59.6(\mathrm{Q} 3)$. Experts agreed on the fact that the mass (in $\mathrm{kg}$ ) of supplementary feeding provided during the active season is relatively similar among European countries, and it was estimated as 0.8 (Q1), 3.45 (Q2) and 6.15 (Q3). The estimated percentage of carbohydrates in syrup provided before the non-active season (i.e. for preparing wintering colonies) was $52.66(\mathrm{Q} 1), 64.48(\mathrm{Q} 2)$ and $75.84(\mathrm{Q} 3)$. This outcome reflects the fact that, when colder temperatures are approaching, European beekeepers prefer to feed honey bee colonies with highly concentrated syrup or solid products (i.e. candy). Experts agreed that the mass of syrup supplied to colonies before the nonactive season follows a latitudinal gradient. The highest mass (in $\mathrm{kg}$ ) of syrup provided to colonies before the non-active season was estimated for north Europe $(\mathrm{Q} 1=4.18 ; \mathrm{Q} 2=10.96$; $\mathrm{Q} 3=20.30)$, followed by central Europe $(\mathrm{Q} 1=2.55 ; \mathrm{Q} 2=4.96 ; \mathrm{Q} 3=8.3)$ and south Europe ( $\mathrm{Q} 1=1.57 ; \mathrm{Q} 2=3.97 ; \mathrm{Q} 3=7.26)$. In relation to candy supplements, experts agreed that this type of product is largely used only during the non-active season to feed honey bee colonies. Thus, EKE questions related to candy referred only to this period. It was assumed that the percentage of carbohydrates present in candy commonly reaches in the EU the $80-90 \%$ of the product. Also in this case we observe a latitudinal gradient for the estimation of the total mass (in $\mathrm{kg}$ ) of candy provided to honey bee colonies. The highest mass of candy was estimated for north Europe ( $\mathrm{Q} 1=2.17$; $\mathrm{Q} 2=7.9 ; \mathrm{Q} 3=14.42)$, followed by central Europe $(\mathrm{Q} 1=1.54 ; \mathrm{Q} 2=5.92 ; \mathrm{Q} 3=11.38)$ and south Europe $(\mathrm{Q} 1=$ 0.93; $\mathrm{Q} 2=4.02 ; \mathrm{Q} 3=7.86)$. We assumed that protein-based products used to feed honey bee colonies are mainly composed by carbohydrates $(\mathrm{Q} 1=69.72 \%$; $\mathrm{Q} 2=83.11 \%$; $\mathrm{Q}=92.47 \%)$ and proteins $(\mathrm{Q} 1=9 \%$; 2 $=17 \%$; $\mathrm{Q} 3=25 \%$ ). We assumed that protein-based products are provided to bees only during the brood period (i.e. presence of brood in the hive) to support the growth of the immatures. The need to provide protein-based products is highly dependent on the availability of pollen in the area surrounding the hive. The estimated total mass (in $\mathrm{kg}$ ) of protein-based feed provided during the brood period was 0.88 (Q1), $2.20(\mathrm{Q} 2)$ and $4.00(\mathrm{Q} 3)$ in north and central Europe, and $1.10(\mathrm{Q} 1)$, $2.00(\mathrm{Q} 2)$ and $3.00(\mathrm{Q} 3)$ in south Europe $(\mathrm{Q} 1=1.10 ; \mathrm{Q} 2=2.00 ; \mathrm{Q} 3$ $=3.00)$.

\section{Change in the number of workers: guiding principles for applica- tion and effects}

This BMP refers to the transfer of workers from a honey bee colony to another one. This practice might involve the addition of bees in the form of "package bees" (a wire box usually containing $1 \mathrm{Kg}$ of bees, corresponding to approximately 10,000 honey bees) or by shaking one or more frames of bees from one or more donor colonies to a receiver colony.

\subsection{Elements guiding the decision}

Worker bees are typically moved from a donor colony (it should be a colony in good sanitary conditions containing a large number of bees) to a receiver colony (typically containing a low number of bees), with the aim of strengthening and increasing the productivity of the receiver colony. At apiary level, this BMP can be used to homogenize the strength of the colonies that live in proximity, to reduce robbing behaviours and facilitate beekeeping operations (e.g. placing of supers) and to prevent swarming behaviours. Furthermore, the commercialization of nukes and packages of adult worker bees is a common practice, and it is a relevant source of income for beekeepers, especially in spring (Punnett and Winston, 1989).

\subsection{Effects}

- Demography: this action directly affects the demography of a honey bee colony. The number of worker bees will decrease in the donor colony and increase in the receiver colony. Donor colony may experience brood mortality due to the low number of nurse bees available to rear and feed brood when the ratio between the number of adult bees and brood cells is below 0.5 (Woyke, 1984). Furthermore, nurse bees may experience an increased mortality due to the increased nursing load;

- Sanitary conditions: the receiver colony, because of the increased adult/brood ratio, might benefit in terms of reduced pest and pathogen load. However if workers added are infested by varroa, viruses or bacteria, the risks of disease might increase in the receiver colony (Bailey and Ball, 1991; Fries, 1993); 
- In-hive products: studies show the positive correlation between the number of worker bees in a colony and the amount of honey produced (Neupane et al., 2012; Gąbka, 2014).

\subsection{Covariates}

Depending on market request and beekeeper's marketing strategies, this BMP may be implemented to produce new nukes. The timing and frequency of this BMP is highly related to seasonality (Butler, 1945), though it is usually applied in the spring.

\subsection{EKE results}

Pratt (2004) provided some information on general comb composition. We relied on EKE for the estimation of the number of workers present in a comb full of honey bees and the number of honey bees transferred during the active season (Tables S30 and S31). We assume that this BMP is performed only during the active season. The estimated number of honey bees in a worker comb was 1207 (Q1), 2274 (Q2) and 3572 (Q3). The estimated number of honey bees transferred during the active season in a colony was 1312 (Q1), 3497 (Q2) and 6115 (Q3).

\section{Beekeeper category and experience}

We categorized beekeepers based on their main source of income: beekeeping represents the main source of income for professional beekeepers, while non-professional beekeepers has other main sources of income. Beekeepers' experience is defined according to different variables, such as years of practices, qualifications obtained, membership to a beekeeping association, (for a review see EFSA AHAW Panel, 2016). Beekeepers might be also classified depending on the type of production system adopted (i.e. conventional or organic) (Commission Regulation EC No 834/2007, European Commission, 2007; Commission Regulation EC No 836/2014, European Commission, 2014).

\subsection{Effects}

- Demography: beekeeper experience and category influence the ability to understand and cope with the health status of the colonies. The actions carried out by a beekeeper might influence colony demography, physiology and behaviour depending on his/her category and experience. Depending on the capacity of the beekeeper to treat colonies, this BMP influences also the exposure of bees to chemicals (e.g. anti-varroa treatments);

- Sanitary conditions: depending on the category and the level of experience of the beekeeper, his/her actions might influence the prevalence of biological agents within a honey bee colony. For example, the capacity of recognizing symptoms of disease and of taking appropriate measures is influenced by the beekeeper's category and experience;

- In-hive products: beekeeper experience/category influences the quality and quantity of in-hive products.

\subsection{Covariates}

According to previous studies and current definitions used in regulatory documents (Chauzat et al., 2013; EFSA, 2016; EFSA AHAW Panel, 2016; Jacques et al., 2016), the beekeeper category assessment is based on the level of income generated by beekeeping (i.e. whether the activity generates a "significant source of income"). In addition, the number of colonies managed by the beekeeper could be used as further variable to define the categories of beekeepers across EU. In 2015, 96\% of European beekeepers were considered "non-professional" (as they manage less than 150 beehives) whereas only $4 \%$ of beekeepers in the EU had more than 150 beehives and could be classified as "professional" beekeepers. However, this threshold seems to be inappropriate. Some beekeeping associations suggest considering 40 hives as a threshold to distinguish non-professional from professional beekeepers. Training for beekeepers is compulsory only in Portugal and Romania. In five countries, (Portugal, Hungary, Romania, Slovakia and Spain) beekeepers need to receive approval by a competent authority before starting the beekeeping activity.

\section{Conclusions}

In this paper, we provided the first generalizable conceptual framework for the characterization of the actions carried out by beekeepers (BMPs) in Europe. The study focused on the following BMPs: chemical control; replacement of combs with brood; replacement of combs with feed sources; supplementary feeding; change in the number of workers; beekeeper category and experience. We have further defined the BMPs according to three descriptors: the elements guiding their application, the effects to a honey bee colony, and the covariates influencing their frequency, timing and effectiveness. We performed a literature review for collecting data and information on the BMPs and we performed an Expert Knowledge Elicitation (EKE) for estimating the uncertainty distribution related to relevant aspects of the BMPs. The EKE approach represented an easy and structured way for generating and making available expertise and knowledge about the potential role of the beekeepers to honey bee colonies. To the best of our knowledge, this was the first time that this approach is applied within this field. The outcomes of this study represent a step forward on the characterization and quantification of the role of beekeepers on ensuring the health and productivity of honey bees. This work might be useful for defining and quantifying the role of the beekeeper to honey bee health and for the implementation of tools supporting knowledge-based risk management actions. Furthermore, data and estimations provided might be useful for the development of realistic scenarios related to European beekeeping and provide a valid support for the development of modelling tools (e.g. honey bee health indexes and/or models on honey bee population dynamics) able to capture the influence of the beekeeper to a honey bee colony (Gilioli et al., 2018, 2019). The conceptual framework that we developed is independent from the selection of the BMPs. Therefore, the same scheme may be applied for the definition of each beekeeping action considered relevant based on the purpose of the study. Further advancements might include the circulation of the EKE survey to a larger public (e.g. beekeeping associations, professional and non-professional beekeepers etc.) with the aim to reduce uncertainty and fine-tune the estimated quantiles.

\section{Declaration of competing interest}

None.

\section{Acknowledgement}

This research has been partially supported by "Fondazione Cariplo" (Italy) and "Regione Lombardia" (Italy) under the project: "La salute della persona: lo sviluppo e la valorizzazione della conoscenza per la prevenzione, la diagnosi precoce e le terapie personalizzate". Grant Emblematici Maggiori 2015-1080.

\section{Appendix A. Supplementary data}

Supplementary data to this article can be found online at https://doi. org/10.1016/j.scitotenv.2019.133795.

\section{References}

Aguilar, R., Ashworth, L., Galetto, L., Aizen, M.A., 2006. Plant reproductive susceptibility to habitat fragmentation: review and synthesis through a meta-analysis. Ecol. Lett. 9, 968-980. https://doi.org/10.1111/j.1461-0248.2006.00927.x.

Akyol, E., Yeninar, H., Sahinler, N., Guler, A., 2006. The effects of additive feeding and feed additives before wintering on honey bee colony performances, wintering abilities 
and survival rates at the East Mediterranean region. Pak. J. Biol. Sci. 9, 589-592. https://doi.org/10.3923/pjbs.2006.589.592.

Aliano, N.P., Ellis, M.D., Siegfried, B.D., 2006. Acute contact toxicity of oxalic acid to Varroa destructor (Acari: Varroidae) and their Apis mellifera (Hymenoptera: Apidae) hosts in laboratory bioassays. J. Econ. Entomol. 99, 1579-1582 (doi:10.1603/ 0022-049399.5.1579).

Allen, M.D., Jeffree, E.P., 1956. The influence of stored pollen and of colony size on the brood rearing of honeybees. Ann. Appl. Biol. 44, 649-656. https://doi.org/10.1111/ j.1744-7348.1956.tb02164.x.

Ashman, T.-L., Knight, T.M., Steets, J.A., Amarasekare, P., Burd, M., Campbell, D.R., Dudash, M.R., Johnston, M.O., Mazer, S.J., Mitchell, R.J., Morgan, M.T., Wilson, W.G., 2004. Pollen limitation of plant reproduction: ecological and evolutionary causes and consequences. Ecology 85, 2408-2421. https://doi.org/10.1890/03-8024.

Atkins, E.L., Kellum, D., Atkins, K.W., 1981. Reducing Pesticide Hazards to Honey Bees: Mortality Prediction Techniques and Integrated Management Strategies. Leafl. Univ. California, Coop. Ext. Serv.

Bailey, L., Ball, B.V., 1991. Honey bee pathology. 2nd edition. Academic Press, New-York https://doi.org/10.1146/annurev.en.13.010168.001203 208 pp.

Bogdanov, S., 2006. Contaminants of bee products. Apidologie 37, 1-18. https://doi.org/ 10.1051/apido:2005043.

Bogdanov, S., Charrière, J-D., Imdorf, A., Kilchenmann, V., Fluri, P., 2002. Determination of residues in honey after treatments with formic and oxalic acid under field conditions. Apidologie 33, 399-409. https://doi.org/10.1051/apido:2002029.

Boi, M., Serra, G., Colombo, R., Lodesani, M., Massi, S., Costa, C., 2016. A 10 year survey of acaricide residues in beeswax analysed in Italy. Pest Manag. Sci. 72, 1366-1372. https://doi.org/10.1002/ps.4161.

Bommarco, R., Marini, L., Vaissière, B.E., 2012. Insect pollination enhances seed yield, quality, and market value in oilseed rape. Oecologia 169, 1025-1032. https://doi.org/ 10.1007/s00442-012-2271-6.

Boncristiani, H., Underwood, R., Schwarz, R., Evans, J.D., Pettis, J., vanEngelsdorp, D., 2012. Direct effect of acaricides on pathogen loads and gene expression levels in honey bees Apis mellifera. J. Insect Physiol. 58, 613-620. https://doi.org/10.1016/J. JINSPHYS.2011.12.011.

Brandt, A., Gorenflo, A., Siede, R., Meixner, M., Büchler, R., 2016. The neonicotinoids thiacloprid, imidacloprid, and clothianidin affect the immunocompetence of honey bees (Apis mellifera L.). J. Insect Physiol. 86, 40-47. https://doi.org/10.1016/j. jinsphys.2016.01.001.

Brodschneider, R., Crailsheim, K., 2010. Nutrition and health in honey bees. Apidologie 41, 278-294. https://doi.org/10.1051/apido/2010012.

Brodschneider, R., Gray, A., van der Zee, R., Adjlane, N., Brusbardis, V., Charrière, J.-D., Chlebo, R., Coffey, M.F., Crailsheim, K., Dahle, B., Danihlík, J., Danneels, E., de Graaf, D.C., Dražić, M.M., Fedoriak, M., Forsythe, I., Golubovski, M., Gregorc, A., Grzęda, U., Hubbuck, I., İvgin Tunca, R., Kauko, L., Kilpinen, O., Kretavicius, J., Kristiansen, P., Martikkala, M., Martín-Hernández, R., Mutinelli, F., Peterson, M., Otten, C., Ozkirim, A., Raudmets, A., Simon-Delso, N., Soroker, V., Topolska, G., Vallon, J., Vejsnæs, F., Woehl, S., 2016. Preliminary analysis of loss rates of honey bee colonies during winter 2015/16 from the COLOSS survey. J. Apic. Res. 55, 375-378. https://doi.org/10.1080/ 00218839.2016 .1260240 .

Brosi, B.J., Daily, G.C., Ehrlich, P.R., 2007. Bee community shifts with landscape context in a tropical countryside. Ecol. Appl. 17, 418-430. https://doi.org/10.1890/06-0029.

Büchler, R., Costa, C., Hatjina, F., Andonov, S., Meixner, M.D., Le Conte, Y., Uzunov, A., Berg, S., Bienkowska, M., Bouga, M., Drazic, M., Dyrba, W., Panasiuk, B., Pechhacker, H., Petrov, P., Kezić, N., Korpela, S., Wilde, J., 2014. The influence of genetic origin and its interaction with environmental effects on the survival of Apis mellifera L. colonies in Europe. J. Apic. Res. 53, 205-214. https://doi.org/10.3896/IBRA.1.53.2.03.

Burkle, L.A., Marlin, J.C., Knight, T.M., 2013. Plant-pollinator interactions over 120 years: loss of species, co-occurrence, and function. Science 339, 1611-1615. https://doi. org/10.1126/science.1232728.

Butler, C.G., 1945. The influence of various physical and biological factors of the environment on honeybee activity. An examination of the relationship between activity and nectar concentration and abundance. J. Exp. Biol. 21, 5-12.

Calis, J.N.M., Boot, W.J., Beetsma, J., van den Eijnde, J.H.P.M., de Ruijter, A., van der Steen, J.J.M., 1998. Control of varroa by combining trapping in honey bee worker brood with formic acid treatment of the capped brood outside the colony: putting knowledge on brood cell invasion into practice. J. Apic. Res. 37, 205-215. https://doi.org/ 10.1080/00218839.1998.11100973.

Cepero, A., Ravoet, J., Gómez-Moracho, T., Bernal, J.L., Del Nozal, M.J., Bartolomé, C., Maside, X., Meana, A., González-Porto, A.V., De Graaf, D.C., Martín-Hernández, R., Higes, M., 2014. Holistic screening of collapsing honey bee colonies in Spain: a case study. BMC research notes 7, 649. https://doi.org/10.1186/1756-0500-7-649.

Charriére, J.-D., Imdorf, A., 2002. Oxalic acid treatment by trickling against Varroa destructor: recommendations for use in Central Europe and under temperate climate conditions. Bee World 83, 51-60. https://doi.org/10.1080/0005772X.2002.11099541.

Chauzat, M.P., Jacques, A., Laurent, M., Bougeard, S., Hendrikx, P., Ribière-Chabert, M., EPILOBEE Consortium, 2016. Risk indicators affecting honeybee colony survival in Europe: one year of surveillance. Apidologie 47, 348-378. https://doi.org/10.1007/ s13592-016-0440-z.

Chauzat, M.-P., Cauquil, L., Roy, L., Franco, S., Hendrikx, P., Ribière-Chabert, M., 2013. Demographics of the European apicultural industry. PLoS One 8, e79018. https://doi.org/ 10.1371/journal.pone.0079018.

Chauzat, P., Laurent, M., Rivière, M.P., Saugeon, C., Hendrikx, P., Ribière-Chabert, M., 2014. A Pan-European Epidemiological Study on Honey Bee Colony Losses 2012-2013. European Union Reference Laboratory for Honeybee Health, Brussels (Rapport technique).

Codling, G., Al Naggar, Y., Giesy, J.P., Robertson, A.J., 2016. Concentrations of neonicotinoid insecticides in honey, pollen and honey bees (Apis mellifera L.) in Central
Saskatchewan, Canada. Chemosphere 144, 2321-2328. https://doi.org/10.1016/j. chemosphere.2015.10.135.

Collison, E., Hird, H., Cresswell, J., Tyler, C., 2016. Interactive effects of pesticide exposure and pathogen infection on bee health - a critical analysis. Biol. Rev. 91, 1006-1019. https://doi.org/10.1111/brv.12206.

Cornman, R.S., Tarpy, D.R., Chen, Y., Jeffreys, L., Lopez, D., Pettis, J.S., VanEngelsdorp, D. Evans, J.D., 2012. Pathogen webs in collapsing honey bee colonies. PLoS One 7, e43562. https://doi.org/10.1371/journal.pone.0043562.

Cox-Foster, D.L., Conlan, S., Holmes, E.C., Palacios, G., Evans, J.D., Moran, N.A., Quan, P.-L., Briese, T., Hornig, M., Geiser, D.M., Martinson, V., vanEngelsdorp, D., Kalkstein, A.L., Drysdale, A., Hui, J., Zhai, J., Cui, L., Hutchison, S.K., Simons, J.F., Egholm, M., Pettis, J.S., Lipkin, W.I., 2007. A metagenomic survey of microbes in honey bee colony collapse disorder. Science 318, 283-287. https://doi.org/10.1126/SCIENCE.1146498.

Crane, E., 2004. A short history of knowledge about honey bees (Apis) up to 1800 . Bee World 85, 6-11. https://doi.org/10.1080/0005772X.2004.11099604.

Dadant, C., 1975. The Hive and the Honey Bee. Hamilton. vol. 1324.

Dahlgren, L., Johnson, R.M., Siegfried, B.D., Ellis, M.D., 2012. Comparative toxicity of acaricides to honey bee (Hymenoptera: Apidae) workers and queens. J. Econ. Entomol. 105, 1895-1902. https://doi.org/10.1603/EC12175.

Decourtye, A., Mader, E., Desneux, N., 2010. Landscape enhancement of floral resources for honey bees in agro-ecosystems. Apidologie 41, 264-277. https://doi.org/ 10.1051/apido/2010024.

DeGrandi-Hoffman, G., Curry, R., 2004. A mathematical model of Varroa mite (Varroa destructor Anderson and Trueman) and honeybee (Apis mellifera L.) population dynamics. Int. J. Acarol. 30, 259-274. https://doi.org/10.1080/01647950408684393.

DeGrandi-Hoffman, G., Wardell, G., Ahumada-Segura, F., Rinderer, T., Danka, R., Pettis, J. 2008. Comparisons of pollen substitute diets for honey bees: consumption rates by colonies and effects on brood and adult populations. J. Apic. Res. 47, 265-270. https://doi.org/10.1080/00218839.2008.11101473.

DeGrandi-Hoffman, G., Chen, Y., Huang, E., Huang, M.H., 2010. The effect of diet on protein concentration, hypopharyngeal gland development and virus load in worker honey bees (Apis mellifera L.). J. Insect Physiol. 56, 1184-1191. https://doi.org/10.1016/j. jinsphys.2010.03.017.

DeGrandi-Hoffman, G., Chen, Y., Rivera, R., Carroll, M., Chambers, M., Hidalgo, G., de Jong E.W., 2016. Honey bee colonies provided with natural forage have lower pathogen loads and higher overwinter survival than those fed protein supplements. Apidologie 47, 186-196. https://doi.org/10.1007/s13592-015-0386-6.

Deloitte, 2013. Evaluation of Measures for the Apicultural Sector.Available online. https:// ec.europa.eu/agriculture/sites/agriculture/files/evaluation/market-and-income-reports/2013/apiculture/fulltext_en.pdf (accessed 22 March 2019).

Di Pasquale, G., Salignon, M., Le Conte, Y., Belzunces, L.P., Decourtye, A., Kretzschmar, A. Suchail, S., Brunet, J.-L., Alaux, C., 2013. Influence of pollen nutrition on honey bee health: do pollen quality and diversity matter? PLoS One 8, e72016. https://doi.org/ 10.1371/journal.pone.0072016.

Di Prisco, G., Annoscia, D., Margiotta, M., Ferrara, R., Varricchio, P., Zanni, V., Caprio, E. Nazzi, F., Pennacchio, F., 2016. A mutualistic symbiosis between a parasitic mite and a pathogenic virus undermines honey bee immunity and health. Proc. Natl. Acad. Sci. 113, 3203-3208. https://doi.org/10.1073/pnas.1523515113.

Dively, G.P., Embrey, M.S., Kamel, A., Hawthorne, D.J., Pettis, J.S., 2015. Assessment of chronic sublethal effects of imidacloprid on honey bee colony health. PLoS One 10, e0118748. https://doi.org/10.1371/journal.pone.0118748.

Dodologlu, A., Emsen, B., 2007. Effect of supplementary feeding on honey bee colony J. Appl. Anim. Res. 32, 199-200. https://doi.org/10.1080/09712119.2007.9706878.

EC (European Commission), 2007. Council regulation (EC) no 834/2007 of 28 June 2007 on organic production and labelling of organic products and repealing regulation (EEC) no 2092/91. Off. J. Eur. Union 189, 1-23.

EC (European Commission), 2009. Commission regulation (EC) no. 470/2009 laying down community procedures for the establishment of residue limits of pharmacologically active substances in foodstuffs of animal origin. Off. J. Eur. Union 152, 11-22.

EC (European Commission), 2014. Commission implementing regulation (EU) no 836 2014 of 31 July 2014 amending regulation (EC) no 889/2008 laying down detailed rules for the implementation of council regulation (EC) no 834/2007 on organic production and labelling of organic products with regard to organic production, labelling and control. Off. J. Eur. Union 50, 10-11.

EC (European Commission), 2016. Report from the commission to the European Parliament and the council. On the implementation of the measures concerning the apiculture sector of regulation (EU) no 1308/2013 of the European Parliament and of the council establishing a common organisation of the markets in agricultural products, p. 1-16.

EFSA (European Food Safety Authority), 2014. Guidance on expert knowledge elicitation in food and feed safety risk assessment. EFSA J. 2014;12(6):3734. [278 pp.] doi: https://doi.org/10.2903/j.efsa.2014.3734.

EFSA (European Food Safety Authority), 2016. A mechanistic model to assess risks to honeybee colonies from exposure to pesticides under different scenarios of combined stressors and factors. EFSA Supporting Publication 2016:EN-1069 https://doi.org/ 10.2903/sp.efsa.2016.EN-1069 116 pp.

EFSA (European Food Safety Authority) Scientific Committee, 2018. Guidance on uncertainty analysis in scientific assessments. EFSA J. 16 (1), 5123 2018. 39 pp. https:// doi.org/10.2903/j.efsa.2018.5123.

EFSA AHAW Panel (EFSA Panel on Animal Health and Welfare), 2016. Scientific opinion on assessing the health status of managed honeybee colonies (HEALTHY-B): a toolbox to facilitate harmonised data collection. EFSA J. 14 (10), 4578 2016. 241 pp. https://doi.org/10.2903/j.efsa.2016.4578.

Eischen, F.A., Rothenbuhler, W.C., Kulinčević, J.M., 1983. Brood rearing associated with a range of worker-larva ratios in the honeybee. J. Apic. Res. 22, 163-168. https://doi. org/10.1080/00218839.1983.11100582. 
Eischen, F.A., Rothenbuhler, W.C., Kulinčević, J.M., 1984. Some effects of nursing on nurse bees. J. Apic. Res. 23, 90-93. https://doi.org/10.1080/00218839.1984.11100615.

EMA/CMDv/497311/2009, 2013. Bee Products, Situation in Europe. Co-Ordination Group for Mutual Recognition and Decentralised Procedures-Veterinary. Rev. 13 London, 22 Jun 2018. , pp. 1-51 Available online. https://assets.publishing.service.gov.uk/government/uploads/system/uploads/attachment_data/file/724720/1.4.1.7_QA76_Bee_ products_in_EU_0.40.pdf, Accessed date: 24 April 2019.

Emsen, B., Hamiduzzaman, M.M., Goodwin, P.H., Guzman-Novoa, E., 2015. Lower virus infections in Varroa destructor-infested and uninfested brood and adult honey bees (Apis mellifera) of a low mite population growth colony compared to a high mite population growth colony. PLoS One 10, e0118885. https://doi.org/10.1371/journal. pone.0118885.

Filmer, R.S., 1932. Brood area and colony size as factors in activity of pollination units. J. Econ. Entomol. 25, 336-343. https://doi.org/10.1093/jee/25.2.336.

Floris, I., Satta, A., Garau, V.L., Melis, M., Cabras, P., Aloul, N., 2001. Effectiveness, persistence, and residue of amitraz plastic strips in the apiary control of Varroa destructor. Apidologie 32, 577-585. https://doi.org/10.1051/apido:2001145.

Formato, G., Smulders, F.J.M., 2011. Risk management in primary apicultural production. Part 1: bee health and disease prevention and associated best practices. Vet. Q. 31, 29-47. https://doi.org/10.1080/01652176.2011.565913.

Fries, I., 1993. Nosema apis - a parasite in the honey bee colony. Bee World 74, 5-19. https://doi.org/10.1080/0005772X.1993.11099149.

Gąbka, J., 2014. Correlations between the strength, amount of brood and honey production of the honey bee colony. Med. Weter. 70, 754-756.

Garrido, P.M., Antúnez, K., Martín, M., Porrini, M.P., Zunino, P., Eguaras, M.J., 2013. Immune-related gene expression in nurse honey bees (Apis mellifera) exposed to synthetic acaricides. J. Insect Physiol. 59, 113-119. https://doi.org/10.1016/j. jinsphys.2012.10.019.

Genersch, E., von der Ohe, W., Kaatz, H., Schroeder, A., Otten, C., Büchler, R., Berg, S., Ritter, W., Mühlen, W., Gisder, S., Meixner, M., Liebig, G., Rosenkranz, P., 2010. The German bee monitoring project: a long term study to understand periodically high winter losses of honey bee colonies. Apidologie 41, 332-352. https://doi.org/10.1051/ apido/2010014.

Giacobino, A., Molineri, A.I., Pacini, A., Fondevila, N., Pietronave, H., Rodríguez, G., Palacio A., Bulacio Cagnolo, N., Orellano, E., Salto, C.E., Signorini, M.L., Merke, J., 2016. Varroa destructor and viruses association in honey bee colonies under different climatic conditions. Environ. Microbiol. Rep. 8, 407-412. https://doi.org/10.1111/17582229.12410

Gilioli, G., Simonetto, A., Hatjina, F., Sperandio, G., 2018. Multi-dimensional modelling tools supporting decision-making for the beekeeping sector. IFAC-PapersOnLine 51 144-149. https://doi.org/10.1016/j.ifacol.2018.06.225.

Gilioli, G., Sperandio, G., Hatjina, F., Simonetto, A., 2019. Towards the development of an index for the holistic assessment of the health status of a honey bee colony. Ecol. Indic. 101, 341-347. https://doi.org/10.1016/j.ecolind.2019.01.024.

Goulson, D., Nicholls, E., Botías, C., Rotheray, E.L., 2015. Bee declines driven by combined stress from parasites, pesticides, and lack of flowers. Science 347, 1255957. https:// doi.org/10.1126/science.1255957.

Gray, A., Brodschneider, R., Adjlane, N., Ballis, A., Brusbardis, V., Charrière, J.-D., Chlebo, R. Coffey, M., F., Cornelissen, B., Amaro da Costa, C., Csáki, T., Dahle, B., Danihlík, J., Dražić, M.M., Evans, G., Fedoriak, M., Forsythe, I., de Graaf, D., Gregorc, A., Johannesen, J. Kauko, L., Kristiansen, P., Martikkala, M., Martín-Hernández, R., Medina-Flores, C.A., Mutinelli, F., Patalano, S., Petrov, P., Raudmets, A., Ryzhikov, V.A., Simon-Delso, N. Stevanovic, J., Topolska, G., Uzunov, A., Vejsnaes, F., Williams, A., Zammit-Mangion, M., Soroker, V., 2019. Loss rates of honey bee colonies during winter 2017/18 in 36 countries participating in the COLOSS survey, including effects of forage sources. J. Apic. Res. 58, 479-485. https://doi.org/10.1080/00218839.2019.1615661.

Gregorc, A., Bowen, I.D., 2000. Histochemical characterization of cell death in honeybee larvae midgut after treatment with Paenibacillus larvae, amitraz and oxytetracycline. Cell Biol. Int. 24, 319-324. https://doi.org/10.1006/cbir.1999.0490.

Gregorc, A., Alburaki, M., Werle, C., Knight, P.R., Adamczyk, J., 2017. Brood removal or queen caging combined with oxalic acid treatment to control varroa mites (Varroa destructor) in honey bee colonies (Apis mellifera). Apidologie 48, 821-832. https:// doi.org/10.1007/s13592-017-0526-2.

de Groot, R.S., Wilson, M.A., Boumans, R.M., 2002. A typology for the classification, description and valuation of ecosystem functions, goods and services. Ecol. Econ. 41, 393-408. https://doi.org/10.1016/S0921-8009(02)00089-7.

Haarmann, T., Spivak, M., Weaver, D., Weaver, B., Glenn, T., 2002. Effects of fluvalinate and coumaphos on queen honey bees (Hymenoptera: Apidae) in two commercial queen rearing operations. J. Econ. Entomol. 95, 28-35. https://doi.org/10.1603/0022-049395.1.28.

Harbo, J.R., 1986. Effect of population size on brood production, worker survival and honey gain in colonies of honeybees. J. Apic. Res. 25, 22-29. https://doi.org/ 10.1080/00218839.1986.11100687.

Henry, M., Bertrand, C., Le Féon, V., Requier, F., Odoux, J.-F., Aupinel, P., Bretagnolle, V., Decourtye, A., 2014. Pesticide risk assessment in free-ranging bees is weather and landscape dependent. Nat. Commun. 5, 4359. https://doi.org/10.1038/ncomms5359.

Higes, M., Martín-Hernández, R., Garrido-Bailón, E., González-Porto, A.V., García-Palencia P., Meana, A., del Nozal, M.J., Mayo, R., Bernal, J.L., 2009. Honeybee colony collapse due to Nosema ceranae in professional apiaries. Environ. Microbiol. Rep. 1, 110-113. https://doi.org/10.1111/j.1758-2229.2009.00014.x.

Jacques, A., Laurent, M., Ribiere-Chabert, M., Saussac, M., Bougeard, S., Hendrikx, P. Chauzat, M., 2016. Statistical analysis on the EPILOBEE dataset: explanatory variables related to honeybee colony mortality in EU during a 2 year survey. EFSA Support. Publ. 13. https://doi.org/10.2903/sp.efsa.2016.EN-883.

Jacques, A., Laurent, M., Ribière-Chabert, M., Saussac, M., Bougeard, S., Budge, G.E. Hendrikx, P., Chauzat, M.-P., 2017. A pan-European epidemiological study reveals honey bee colony survival depends on beekeeper education and disease control. PLoS One 12, e0172591. https://doi.org/10.1371/journal.pone.0172591.

Johnson, R.M., 2015. Honey bee toxicology. Annu. Rev. Entomol. 60, 415-434. https://doi. org/10.1146/annurev-ento-011613-162005.

Johnson, R.M., Ellis, M.D., Mullin, C.A., Frazier, M., 2010. Pesticides and honey bee toxicity - USA. Apidologie 41, 312-331. https://doi.org/10.1051/apido/2010018.

Johnson, R.M., Dahlgren, L., Siegfried, B.D., Ellis, M.D., 2013. Acaricide, fungicide and drug interactions in honey bees (Apis mellifera). PLoS One 8, e54092. https://doi.org/ 10.1371/journal.pone.0054092.

Kelley, S., 1991. The Regulation of Comb Building in Honey Bee Colonies. Senior honoris thesis. Cornell University, Ithaca, New York

Knol, A.B., Slottje, P., van der Sluijs, J.P., Lebret, E., 2010. The use of expert elicitation in environmental health impact assessment: a seven step procedure. Environ. Health 9, 19. https://doi.org/10.1186/1476-069X-9-19.

Laurent, M., Hendrikx, P., Ribiere-Chabert, M., Chauzat, M.P., 2015. A panEuropean epidemiological study on honeybee colony losses 2012-2014. EPILOBEE Report.

Le Conte, Y., Mohammedi, A., Robinson, G.E., 2001. Primer effects of a brood pheromone on honeybee behavioural development. Proc. R. Soc. London. Ser. B Biol. Sci. 268, 163-168. https://doi.org/10.1098/rspb.2000.1345.

Le Conte, Y., Ellis, M., Ritter, W., 2010. Varroa mites and honey bee health: can Varroa explain part of the colony losses? Apidologie 41, 353-363. https://doi.org/10.1051/ apido/2010017.

Lindström, A., Korpela, S., Fries, I., 2008. The distribution of Paenibacillus larvae spores in adult bees and honey and larval mortality, following the addition of American foulbrood diseased brood or spore-contaminated honey in honey bee (Apis mellifera) colonies. J. Invertebr. Pathol. 99, 82-86. https://doi.org/10.1016/j.jip.2008.06.010.

Lodesani, M., Costa, C., 2005. Limits of chemotherapy in beekeeping: development of resistance and the problem of residues. Bee World 86, 102-109. https://doi.org/ 10.1080/0005772X.2005.11417324

Lodesani, M., Costa, C., Serra, G., Colombo, R., Sabatini, A.G., 2008. Acaricide residues in beeswax after conversion to organic beekeeping methods. Apidologie 39, 324-333. https://doi.org/10.1051/apido:2008012.

Lodesani, M., Vaccari, G., Franceschetti, S., Bergomi, P., Costa, C., 2012. Effetto della disponibilità di polline sulla suscettibilità della colonia ad alcuni patogeni e sulla longevità delle api. APOidea 1-2.

Lodesani, M., Costa, C., Besana, A., Dall'Olio, R., Franceschetti, S., Tesoriero, D., Giacomo, D., 2014. Impact of control strategies for Varroa destructor on colony survival and health in northern and central regions of Italy. J. Apic. Res. 53, 155-164. https://doi.org/ 10.3896/IBRA.1.53.1.17.

Maggi, M.D., Ruffinengo, S.R., Gende, L.B., Eguaras, M.J., Sardella, N.H., 2008. LC 50 baseline levels of amitraz, coumaphos, fluvalinate and flumethrin in populations of Varroa destructor from Buenos Aires Province, Argentina. J. Apic. Res. 47, 292-295. https:// doi.org/10.1080/00218839.2008.11101477.

Martel, A.-C., Zeggane, S., Aurières, C., Drajnudel, P., Faucon, J.-P., Aubert, M., 2007. Acaricide residues in honey and wax after treatment of honey bee colonies with Apivar ${ }^{\circledR}$ or Asuntol $® 50$. Apidologie 38, 534-544. https://doi.org/10.1051/apido:2007038.

Mattila, H.R., Otis, G.W., 2006. Influence of pollen diet in spring on development of honey bee (Hymenoptera: Apidae) colonies. J. Econ. Entomol. 99, 604-613. https://doi.org/ 10.1603/0022-0493-99.3.604.

McLellan, A.R., 1978. Growth and decline of honeybee colonies and inter-relationships of adult bees, brood, honey and pollen. J. Appl. Ecol. 15, 155. https://doi.org/10.2307/ 2402927.

Mizrahi, A., Lensky, Y. (Eds.), 1997. Bee Products. Springer US, Boston, MA https://doi.org/ 10.1007/978-1-4757-9371-0.

Morris, D.E., Oakley, J.E., Crowe, J.A., 2014. A web-based tool for eliciting probability distributions from experts. Environ. Model. Softw. 52, 1-4. https://doi.org/10.1016/j. envsoft.2013.10.010.

Mortensen, A.N., Jack, C.J., Bustamante, T.A., Schmehl, D.R., Ellis, J.D., 2019. Effects of supplemental pollen feeding on honey bee (Hymenoptera: Apidae) colony strength and Nosema spp. infection. J. Econ. Entomol. 112, 60-66. https://doi.org/10.1093/jee/ toy341.

Mullin, C.A., Frazier, M., Frazier, J.L., Ashcraft, S., Simonds, R., VanEngelsdorp, D., Pettis, J.S., 2010. High levels of miticides and agrochemicals in North American apiaries: implications for honey bee health. PLoS One 5, e9754. https://doi.org/10.1371/journal. pone.0009754.

Mutinelli, F., 2016. Veterinary medicinal products to control Varroa destructor in honey bee colonies (Apis mellifera) and related EU legislation - an update. J. Apic. Res. 55, 78-88. https://doi.org/10.1080/00218839.2016.1172694.

Mutinelli, F., Rademacher, E., 2003. The use of drugs to control varroosis in honey bee colonies and European legislation: the current situation. Bee World 84, 55-59. https:// doi.org/10.1080/0005772X.2003.11099577.

Nanetti, A., Büchler, R., Uzunov, A., Gregorc, A., 2016. Coloss-varroa control taskforce, brood interruption study 2016/2017. Available online:. https://coloss.org/taskforces/Coloss SEASONAL-BROOD-INTERRUPTION-STUDY-2016.pdf, Accessed date: 22 March 2019.

Naug, D., 2009. Nutritional stress due to habitat loss may explain recent honeybee colony collapses. Biol. Conserv. 142, 2369-2372. https://doi.org/10.1016/j. biocon.2009.04.007.

Nazzi, F., Brown, S.P., Annoscia, D., Del Piccolo, F., Di Prisco, G., Varricchio, P., Della Vedova, G., Cattonaro, F., Caprio, E., Pennacchio, F., 2012. Synergistic parasitepathogen interactions mediated by host immunity can drive the collapse of honeybee colonies. PLoS Pathog. 8, e1002735. https://doi.org/10.1371/journal. ppat.1002735.

Neumann, P., Carreck, N.L., 2010. Honey bee colony losses. J. Apic. Res. 49, 1-6. https://doi. org/10.3896/IBRA.1.49.1.01. 
Neupane, K.R., Woyke, J., Wilde, J., 2012. Effect of initial strength of honey bee colonies (Apis mellifera) supered in different ways on maximizing honey production in Nepal. J. Apic. Sci. 56, 71-81. https://doi.org/10.2478/v10289-012-0025-7.

Odoux, J.-F., Aupinel, P., Gateff, S., Requier, F., Henry, M., Bretagnolle, V., 2014. ECOBEE: a tool for long-term honey bee colony monitoring at the landscape scale in West European intensive agroecosystems. J. Apic. Res. 53, 57-66. https://doi.org/10.3896/ IBRA.1.53.1.05.

Pankiw, T., 2004. Brood pheromone regulates foraging activity of honey bees (Hymenoptera: Apidae). J. Econ. Entomol. 97, 748-751. https://doi.org/10.1093/jee/97.3.748.

Pankiw, T., Roman, R., Sagili, R.R., Zhu-Salzman, K., 2004. Pheromone-modulated behavioral suites influence colony growth in the honey bee (Apis mellifera). Naturwissenschaften 91, 575-578. https://doi.org/10.1007/s00114-004-0568-y.

Pettis, J.S., Collins, A.M., Wilbanks, R., Feldlaufer, M.F., 2004. Effects of coumaphos on queen rearing in the honey bee, Apis mellifera. Apidologie 35, 605-610. https://doi. org/10.1051/apido:2004056.

Porrini, C., Mutinelli, F., Bortolotti, L., Granato, A., Laurenson, L., Roberts, K., Gallina, A., Silvester, N., Medrzycki, P., Renzi, T., Sgolastra, F., Lodesani, M., 2016. The status of honey bee health in Italy: results from the nationwide bee monitoring network. PLoS One 11, e0155411. https://doi.org/10.1371/journal.pone.0155411.

Pratt, S.C., 2004. Collective control of the timing and type of comb construction by honey bees (Apis mellifera). Apidologie 35, 193-205. https://doi.org/10.1051/apido: 2004005.

Pufal, G., Steffan-Dewenter, I., Klein, A.-M., 2017. Crop pollination services at the landscape scale. Curr. Opin. Insect Sci. 21, 91-97. https://doi.org/10.1016/j. cois.2017.05.021.

Punnett, E.N., Winston, M.L., 1989. A comparison of package and nucleus production from honey bee (Apis mellifera L.) colonies. Apidologie 20, 465-472. https://doi.org/ 10.1051/apido:19890602.

Rademacher, E., Harz, M., 2006. Oxalic acid for the control of varroosis in honey bee colonies - a review. Apidologie 37, 98-120. https://doi.org/10.1051/apido:2005063.

Rangel, J., Tarpy, D.R., 2015. The combined effects of miticides on the mating health of honey bee (Apis mellifera L.) queens. J. Apic. Res. 54, 275-283. https://doi.org/ 10.1080/00218839.2016.1147218.

Rashad, S.E.-D., Parker, R.L., 1958. Pollen as a limiting factor in brood rearing and honey production during three drought years, 1954, 1955, and 1956. Trans. Kansas Acad. Sci. 61, 237. https://doi.org/10.2307/3626440.

Renzi, M.T., Amichot, M., Pauron, D., Tchamitchian, S., Brunet, J.-L., Kretzschmar, A., Maini, S., Belzunces, L.P., 2016. Chronic toxicity and physiological changes induced in the honey bee by the exposure to fipronil and Bacillus thuringiensis spores alone or combined. Ecotoxicol. Environ. Saf. 127, 205-213. https://doi.org/10.1016/j. ecoenv.2016.01.028.

Ritter, W., Akratanakul, P., 2006. Honey Bee Diseases and Pests: A Practical Guide. FAO, Rome. Italy. vol. 4.

Rortais, A., Arnold, G., Dorne, J.-L., More, S.J., Sperandio, G., Streissl, F., Szentes, C., Verdonck, F., 2017. Risk assessment of pesticides and other stressors in bees: principles, data gaps and perspectives from the European food safety authority. Sci. Total Environ. 587-588, 524-537. https://doi.org/10.1016/j.scitotenv.2016.09.127.

Rose, T., Kremen, C., Thrupp, A., Gemmill-Herren, B., Graub, B., Azzu, N., 2014. Policy Analysis Paper: Policy Mainstreaming of Biodiversity and Ecosystem Services with a Focus on Pollination. Food and Agricultural Organisation of United Nations, Rome, Italy.

Rosenkranz, P., Aumeier, P., Ziegelmann, B., 2010. Biology and control of Varroa destructor. J. Invertebr. Pathol. 103, S96-S119. https://doi.org/10.1016/j.jip.2009.07.016.

Saffari, A., Kevan, P.G., Atkinson, J.L., 2010. Palatability and consumption of pattyformulated pollen and pollen substitutes and their effects on honeybee colony performance. J. Apic. Sci. 54, 63-69.

Sammataro, D., Untalan, P., Guerrero, F., Finley, J., 2005. The resistance of varroa mites (Acari: Varroidae) to acaricides and the presence of esterase. Int. J. Acarol. 31, 67-74. https://doi.org/10.1080/01647950508684419.

Schmehl, D.R., Teal, P.E.A., Frazier, J.L., Grozinger, C.M., 2014. Genomic analysis of the interaction between pesticide exposure and nutrition in honey bees (Apis mellifera). J. Insect Physiol. 71, 177-190. https://doi.org/10.1016/j.jinsphys.2014.10.002.
Schmickl, T., Crailsheim, K., 2001. Cannibalism and early capping: strategy of honeybee colonies in times of experimental pollen shortages. J. Comp. Physiol. A. 187, 541-547.

Schmidt, J.O., 1997. Bee Products. In Bee Products. Springer, Boston, MA, pp. 15-26 https://doi.org/10.1007/s003590100226.

Schneider, S., Eisenhardt, D., Rademacher, E., 2012. Sublethal effects of oxalic acid on Apis mellifera (Hymenoptera: Apidae): changes in behaviour and longevity. Apidologie 43, 218-225. https://doi.org/10.1007/s13592-011-0102-0.

Seeley, T.D., 1995. The Wisdom of the Hive: The Social Physiology of Honey Bee Colonies. Harvard University Press, Cambridge, MA.

Seeley, T.D., Morse, R.A., 1976. The nest of the honey bee (Apis mellifera L.). Insect. Soc. 23, 495-512. https://doi.org/10.1007/BF02223477.

Shimshoni, J.A., Sperling, R., Massarwa, M., Chen, Y., Bommuraj, V., Borisover, M., Barel, S. 2019. Pesticide distribution and depletion kinetic determination in honey and beeswax: model for pesticide occurrence and distribution in beehive products. PLoS One 14, e0212631. https://doi.org/10.1371/journal.pone.0212631.

Somerville, D.C., Nicol, H.I., 2006. Crude protein and amino acid composition of honey bee-collected pollen pellets from south-East Australia and a note on laboratory disparity. Aust. J. Exp. Agric. 46, 141. https://doi.org/10.1071/EA03188.

Spurgeon, D., Hesketh, H., Lahive, E., Svendsen, C., Baas, J., Robinson, A., Horton, A., Heard, M., 2016. Chronic oral lethal and sub-lethal toxicities of different binary mixtures of pesticides and contaminants in bees (Apis mellifera, Osmia bicornis and Bombus terrestris). EFSA Support. Publ. 13. https://doi.org/10.2903/sp.efsa.2016.EN-1076.

van der Steen, J., 2007. Effect of a home-made pollen substitute on honey bee colony development. J. Apic. Res., 114-119 https://doi.org/10.3896/IBRA.1.46.2.09.

Steinhauer, N., Kulhanek, K., Antúnez, K., Human, H., Chantawannakul, P., Chauzat, M.-P., VanEngelsdorp, D., 2018. Drivers of colony losses. Curr. Opin. Insect Sci. 26, 142-148. https://doi.org/10.1016/j.cois.2018.02.004.

Tosi, S., Nieh, J.C., Sgolastra, F., Cabbri, R., Medrzycki, P., 2017. Neonicotinoid pesticides and nutritional stress synergistically reduce survival in honey bees. Proc. R. Soc. B Biol. Sci. 284, 20171711. https://doi.org/10.1098/rspb.2017.1711.

Tosi, S., Costa, C., Vesco, U., Quaglia, G., Guido, G., 2018. A 3-year survey of Italian honey bee-collected pollen reveals widespread contamination by agricultural pesticides. Sci. Total Environ. 615, 208-218. https://doi.org/10.1016/j.scitotenv.2017.09.226.

Traynor, K.S., Pettis, J.S., Tarpy, D.R., Mullin, C.A., Frazier, J.L., Frazier, M., VanEngelsdorp, D. 2016. In-hive pesticide exposome: assessing risks to migratory honey bees from inhive pesticide contamination in the eastern United States. Sci. Rep. 6, 33207. https://doi.org/10.1038/srep33207.

Whittington, R., Winston, M.L., Melathopoulos, A.P., Higo, H.A., 2000. Evaluation of the botanical oils neem, thymol, and canola sprayed to control Varroa jacobsoni Oud.(Acari: Varroidae) and Acarapis woodi (Acari: Tarsonemidae) in colonies of honey bees (Apis mellifera L., Hymenoptera: Apidae). Am. Bee J 140, 567-572.

Woyke, J., 1984. Correlations and interactions between population, length of worker life and honey production by honeybees in a temperate region. J. Apic. Res. 23, 148-156. https://doi.org/10.1080/00218839.1984.11100624.

Wu, J.Y., Anelli, C.M., Sheppard, W.S., 2011. Sub-lethal effects of pesticide residues in brood comb on worker honey bee (Apis mellifera) development and longevity. PLoS One 6, e14720. https://doi.org/10.1371/journal.pone.0014720.

van der Zee, R., Brodschneider, R., Brusbardis, V., Charrière, J.-D., Chlebo, R., Coffey, M.F. Dahle, B., Drazic, M.M., Kauko, L., Kretavicius, J., Kristiansen, P., Mutinelli, F., Otten, C., Peterson, M., Raudmets, A., Santrac, V., Seppälä, A., Soroker, V., Topolska, G. Vejsnæs, F., Gray, A., 2014. Results of international standardised beekeeper surveys of colony losses for winter 2012-2013: analysis of winter loss rates and mixed effects modelling of risk factors for winter loss. J. Apic. Res. 53, 19-34. https://doi.org/ 10.3896/IBRA.1.53.1.02.

Zheng, H.-Q., Gong, H.-R., Huang, S.-K., Sohr, A., Hu, F.-L., Chen, Y.P., 2015. Evidence of the synergistic interaction of honey bee pathogens Nosema ceranae and deformed wing virus. Vet. Microbiol. 177, 1-6. https://doi.org/10.1016/j.vetmic.2015.02.003.

Zhu, W., Schmehl, D.R., Mullin, C.A., Frazier, J.L., 2014. Four common pesticides, their mixtures and a formulation solvent in the hive environment have high oral toxicity to honey bee larvae. PLoS One 9, e77547. https://doi.org/10.1371/journal.pone.0077547. 